\title{
EXPLORATORY CELL RESEARCH AND FUNDAMENTAL PROCESSES STUDY IN SOLID STATE ELECTROCHEMICAL CELLS
}

Final Report

June 1990

by

\section{William H. Smyrl \\ Boone B. Owens \\ Henry S. White}

University of Minnesota

Department of Chemical Engineering and Materials Science

Corrosion Research Center

Minneapolis, Minnesota 55455

\author{
for \\ Technology Base Research Project \\ Applied Science Division \\ Lawrence Berkeley Laboratory \\ Berkeley, California 94720
}

This work was supported by the Assistant Secretary for Conservation and Renewable Energy, Deputy Assistant Secretary for Utility Technologies, Office of Energy Management, Advanced Utility Concepts Division of the U.S. Department of Energy under Contract No. DE-AC03-76SF(x)(998, Subcontract No. 4553710 with the Lawrence Berkeley Laboratory. 


\section{INTRODLCTION}

Last year this program demonstrated that alternatives to lithium had some merit on which to base new polymer electrolyte batteries and other electrochemical devices. We reported that $\mathrm{Na}, \mathrm{Zn}$, and $\mathrm{Cu}$ electrolytes have modest conductivities at 10()$^{\circ} \mathrm{C}$. Some preliminary cell cycling data were reported with $\mathrm{V}_{6} \mathrm{O}_{13}$ insertion cathodes, and the successful cell cycling suggested that $\mathrm{N}^{+}, \mathrm{Zn}^{+2}$, and $\mathrm{Cu}^{+2}$ could be inserted and removed reversibly in the cathode material. Also, thin-film polymer cathodes were shown by impedance measurements to have three characteristic regions of behavior. Each region had different controlling processes with relaxation time constants that could be separated with careful manipulation of film thickness, morphology, and charging level.

The present report gives results of the continuation of these studies. In particular, the sodium system was studied more intensively with conductivity measurements on sodium triflate in poly(ethyleneoxide)(PEO), and cell studies with $\mathrm{V}_{6} \mathrm{O}_{13}$ and poly(pyrrole)(PPY) cathodes. The impedance work was concluded and several directions of new work in that area were identified. The insertion studies with single crystal $\mathrm{V}_{6} \mathrm{O}_{13}$ were concluded on this program and transferred to NSF funding.

The thrust of the program was to investigate thin-film polymer electrolyte systems and exploratory cells. Lithium systems have been the subject of extensive investigations in several laboratories in the last several years, and in our laboratory as well. Thin-film cells with total thickness of under 100 microns have been fabricated in our laboratory. With the success of such investigations continuing to spur more extensive interest in roomtemperature electrolytes, other metal systems have more interest as potential alternatives to lithium. The advantages of alternative anode materials such as $\mathrm{Na}, \mathrm{Mg}, \mathrm{Ca}$, and $\mathrm{Zn}$ are (i) reasonable energy densities, (ii) inexpensive, and (iii) abundant supply. Thus, the relatively more advanced $\mathrm{Li}$ systems provide a basis on which to study the alternative anodes with the same solvent (PEO), and the same cathode material ( $\mathrm{V}_{6} \mathrm{O}_{13}, \mathrm{PPY}$, etc.). We have adopted that approach to utilize our in-house capabilities to fabricate exploratory 
cells, and to complement cell cycling studies with investigation of the various electrolytes and insertion cathodes. In Table 1 is shown the theoretical energy density of Li/insertion cathode cells. The $\mathrm{V}_{6} \mathrm{O}_{13}$ cathode has very high energy density, based on the insertion of 8 $\mathrm{Li} /$ mole of the oxide. The energy density of the equivalent $\mathrm{Na}$ cell is $640 \mathrm{Wh} / \mathrm{kg}$ versus 890 for the Li system. As will be shown below, the measured energy density for the first discharge of a $\mathrm{Na}$ cell was lower, i.e., $260 \mathrm{Wh} / \mathrm{kg}$.

Table I. Theoretical Energy Density of Lithium/Intercalation Cathode Cells

\begin{tabular}{|c|c|c|c|c|c|c|c|c|}
\hline CATHODE & $\mathrm{TiS}_{2}$ & $\mathrm{VSe}_{2}$ & $\mathrm{TiSe}_{2}$ & $\mathrm{VS}_{2}$ & $\mathrm{NbSe}_{2}$ & $\mathrm{MoS}_{2}$ & $\mathrm{~V}_{6} \mathrm{O}_{13}$ & $\mathrm{~V}_{2} \mathrm{O}_{5}$ \\
\hline E.D./Wh/kg & 481 & 246 & 243 & 505 & 216 & 300 & 890 & 440 \\
\hline
\end{tabular}

In Table II are listed previous results of the open circuit voltage of several alternative anode materials, including data obtained at the University of Minnesota. In Table III are listed the results from a Chinese group on $\mathrm{Mg}$ and $\mathrm{Zn}$ with montmorillonite electrolyte, and a British group with PEO-based electrolytes. The cycling data in Table III represents most of the work reported in the literature that had been carried out previous to the present study. Patrick et al. found that $\mathrm{Mg}$ anodes always outperformed $\mathrm{Zn}$ or $\mathrm{Al}$ anodes with $\mathrm{TiS}_{2}$ cathodes in the PEO systems whatever salt was used.

Divalent salt polymer electrolytes have shown modest conductivities, and selected results are listed in Table IV. If one assumes that the transference number of each ion is 
Table II. Initial OCVs of Polymer Cells.

\begin{tabular}{|c|c|c|c|}
\hline Cell Type & $\mathrm{OCV}$ & $\operatorname{Ti}\left({ }^{\circ} \mathrm{C}\right)$ & Ref. \\
\hline $\mathrm{Na}\left|(\mathrm{PEO})_{10} \cdot \mathrm{NaI}\right| \mathrm{V}_{6} \mathrm{O}_{13}$ & 2.76 & 90 & $\mathrm{U}$ of $\mathrm{M}$ \\
\hline $\mathrm{Na}\left|(\mathrm{PEO})_{10} \cdot \mathrm{NaBr}\right| \mathrm{V}_{6} \mathrm{O}_{13}$ & 3.09 & 90 & $U$ of $M$ \\
\hline $\mathrm{Na}\left|(\mathrm{PEO})_{10} \cdot \mathrm{NaCF}_{3} \mathrm{SO}_{3}\right| \mathrm{V}_{6} \mathrm{O}_{13}$ & 3.12 & 90 & $\mathrm{U}$ of $\mathrm{M}$ \\
\hline $\mathrm{Na}\left|(\mathrm{PEO})_{10} \cdot \mathrm{NaI}\right| \mathrm{MoS}_{3}$ & 2.65 & 90 & West et al. \\
\hline $\mathrm{Na}\left|(\mathrm{PEO})_{12} \cdot \mathrm{NaClO}_{4}\right| \beta-\mathrm{V}_{2} \mathrm{O}_{5}$ & 3.20 & 120 & West et al. \\
\hline $\mathrm{Na} /(\mathrm{PEO})_{12} \cdot \mathrm{NaClO}_{4} \mid \mathrm{V}_{3} \mathrm{O}_{8}$ & 3.45 & 120 & West et al. \\
\hline $\mathrm{Na}\left|(\mathrm{PEO})_{12} \cdot \mathrm{NaClO}_{4}\right| \alpha-\mathrm{V}_{2} \mathrm{O}_{5}$ & 2.20 & 120 & West et al. \\
\hline $\mathrm{Na}\left|(\mathrm{PEO})_{4.5} \cdot \mathrm{NaSCN}\right| \mathrm{Na}_{\mathrm{x}} \mathrm{TiS}_{2}$ & $2.4^{*}$ & 80 & Mehrotra et al. \\
\hline $\mathrm{Na}\left|(\mathrm{PEO})_{\text {based }}\right| \mathrm{HCr}_{3} \mathrm{O}_{8}$ & 3.40 & 80 & Koksbang et al. \\
\hline $\mathrm{Na}\left|(\mathrm{PEO}), \mathrm{NaCF}_{3} \mathrm{SO}_{3}\right|$ Graphite & 2.00 & 82 & Ge et al. \\
\hline $\mathrm{Mg}\left|(\mathrm{PEO})_{8} \cdot \mathrm{Mg}\left(\mathrm{ClO}_{4}\right)_{2}\right| \mathrm{V}_{6} \mathrm{O}_{13}$ & 2.00 & 100 & $\mathrm{U}$ of $\mathrm{M}$ \\
\hline $\mathrm{Mg}\left|(\mathrm{PEO})_{8} \cdot \mathrm{MgCl}_{2}\right| \mathrm{V}_{6} \mathrm{O}_{13}$ & 2.00 & 100 & $\mathrm{U}$ of $\mathrm{M}$ \\
\hline $\mathrm{Mg}\left|(\mathrm{PEO})_{16} \cdot \mathrm{MgCl}_{2}\right| \mathrm{V}_{6} \mathrm{O}_{13}$ & 2.11 & 100 & $\mathrm{U}$ of $\mathrm{M}$ \\
\hline $\mathrm{Mg}\left|(\mathrm{PEO})_{15} \cdot \mathrm{Mg}(\mathrm{SCN})_{2}\right| \mathrm{TiS}_{2}$ & 1.70 & 30 & Patrick et al. \\
\hline $\mathrm{Zn}\left|(\mathrm{PEO})_{16} \cdot \mathrm{Zn}\left(\mathrm{CF}_{3} \mathrm{SO}_{3}\right)_{2}\right| \mathrm{V}_{6} \mathrm{O}_{13}$ & 1.19 & 100 & $\mathrm{U}$ of $\mathrm{M}$ \\
\hline $\mathrm{Zn}\left|(\mathrm{PEO})_{16} \cdot \mathrm{Zn}\left(\mathrm{ClO}_{4}\right)_{2}\right| \mathrm{V}_{6} \mathrm{O}_{13}$ & 0.72 & 100 & $\mathrm{U}$ of $\mathrm{M}$ \\
\hline $\mathrm{Cu}\left|(\mathrm{PEO})_{16} \cdot \mathrm{CuCl}_{2}\right| \mathrm{V}_{6} \mathrm{O}_{13}$ & 0.52 & 100 & $\mathrm{U}$ of $\mathrm{M}$ \\
\hline $\mathrm{Ca}\left|(\mathrm{PEO})_{16} \cdot \mathrm{Ca}\left(\mathrm{ClO}_{4}\right)_{2}\right| \mathrm{V}_{6} \mathrm{O}_{13}$ & 2.39 & 100 & $U$ of $M$ \\
\hline $\mathrm{Ca}\left|(\mathrm{PEO})_{16} \cdot \mathrm{CaCl}_{2}\right| \mathrm{V}_{6} \mathrm{O}_{13}$ & 2.16 & 100 & $\mathrm{U}$ of $\mathrm{M}$ \\
\hline
\end{tabular}

* Extrapolated value

0.5 , the diffusion coefficient of the salt may be calculated from the conductivity, and the results of such a calculation are shown in Table $V$ (dilute solution), and Table VI (concentrated solution). The diffusion coefficients for the system are typically $10^{-9}$ to $10^{-10}$ $\mathrm{cm}^{2} / \mathrm{sec}$, as expected for amorphous, solid-state systems. The diffusion coefficients for transport in insertion oxides are often $10^{-12} \mathrm{~cm}^{2} / \mathrm{sec}$, and $10^{-7}$ to $10^{-9} \mathrm{~cm}^{2} / \mathrm{sec}$ in insertion 
polymer cathode materials (see below). One concludes that diffusion limitations in the polymer electrolyte $/ \mathrm{V}_{6} \mathrm{O}_{13}$ system will be dominantly in the oxide, but may be in the electrolyte in polymer electrolyte/polymer cathode systems.

Table III. Cell Cycling Results of Mg and Zn Systems.

\begin{tabular}{lcccc}
\hline \multicolumn{1}{c}{ Cell Type } & $\mathrm{i} / \mu \mathrm{A}$ & Discharge Time/hrs & $\mathrm{T}\left({ }^{\circ} \mathrm{C}\right)$ & Ref. \\
\hline $\mathrm{Mg}\left|(\mathrm{PEO})_{15} \cdot \mathrm{Mg}(\mathrm{SCN})_{2}\right| \mathrm{TiS}_{2}$ & 0.5 & 400 & 25 & Patrick et al. \\
$\mathrm{Mg}\left|(\mathrm{PEO})_{10} \cdot \mathrm{Ca}(\mathrm{SCN})_{2}\right| \mathrm{TiS}_{2}$ & 0.8 & 1000 & 25 & Patrick t al. \\
$\mathrm{Zn}\left|(\mathrm{PEO})_{15} \cdot \mathrm{Zn}\left(\mathrm{ClO}_{4}\right)_{2}\right| \mathrm{TiS}_{2}$ & 0.5 & 300 & 25 & Patrick et al. \\
$\mathrm{Mg}\left|(\mathrm{PEO})_{15} \cdot \mathrm{Mg}\left(\mathrm{ClO}_{4}\right)_{2}\right| \mathrm{V}_{6} \mathrm{O}_{13}$ & 1.0 & 400 & 25 & Patrick et al. \\
$\mathrm{Zn}\left|(\mathrm{PEO})_{15} \cdot \mathrm{Zn}\left(\mathrm{ClO}_{4}\right)_{2}\right| \mathrm{V}_{6} \mathrm{O}_{13}$ & 0.5 & 100 & 25 & Patrick et al. \\
$\mathrm{Zn} \mid(\mathrm{PEO})_{9} \cdot \mathrm{Mg}\left(\mathrm{SCN}_{2} \mid \mathrm{V}_{6} \mathrm{O}_{13}\right.$ & 0.5 & 120 & 25 & Patrick et al. \\
\hline
\end{tabular}


Table IV. Conductivity Data for Divalent Salt/Polyethylene Oxide Polymer as Obtained From the Literature

\begin{tabular}{|c|c|}
\hline Electrolyte & $\begin{array}{l}\text { Conductivity } \\
\mathrm{S} / \mathrm{cm}\end{array}$ \\
\hline $\mathrm{MgCl}_{2}: \mathrm{PEO}_{16}$ & $1.3 \times 10^{-5}(1)$ \\
\hline $\mathrm{ZnCl}_{2}: \mathrm{PEO}_{8}$ & $8 \times 10^{-3}(2)$ \\
\hline $\mathrm{Cu}\left(\mathrm{ClO}_{4}\right)_{2}: \mathrm{PEO}_{12}$ & $9 \times 10^{-2}(2)$ \\
\hline $\mathrm{PbI}_{2}: \mathrm{PEO}_{40}$ & $3.2 \times 10^{-6}(1)$ \\
\hline $\mathrm{PbBr}_{2}: \mathrm{PEO}_{8}$ & $2.5 \times 10^{-6}(1)$ \\
\hline $\mathrm{MgCl}_{2} \mathrm{PEO}_{16}$ & $5 \times 10^{-4}(3)$ \\
\hline $\mathrm{Mg}\left(\mathrm{ClO}_{4}\right)_{2}: \mathrm{PEO}_{18}$ & $7 \times 10^{-3}(4)$ \\
\hline $\mathrm{Mg}(\mathrm{SCN})_{2}: \mathrm{PEO}_{12}$ & $9 \times 10^{-4}(4)$ \\
\hline $\mathrm{Ca}\left(\mathrm{ClO}_{4}\right)_{2}: \mathrm{PEO}_{18}$ & $8 \times 10^{-3}(4)$ \\
\hline $\mathrm{Ca}(\mathrm{SCN})_{2}: \mathrm{PEO}_{18}$ & $1 \times 10^{-5}(4)$ \\
\hline $\mathrm{Zn}\left(\mathrm{ClO}_{4}\right)_{2}: \mathrm{PEO}_{18}$ & $6 \times 10^{-3}(4)$ \\
\hline $\mathrm{NaSCN}: \mathrm{PEO}_{4.5}$ & $7 \times 10^{-3}(5)$ \\
\hline
\end{tabular}

Table V. Calculated Diffusion Coefficient Values for Divalent Polymer Electrolytes

\begin{tabular}{lccc}
\hline Electrolyte & $\begin{array}{c}\text { Conductivity } \\
\mathrm{S} / \mathrm{cm}\end{array}$ & $\begin{array}{c}\text { Transport } \\
\text { Number }\end{array}$ & $\begin{array}{c}\text { Diffusion } \\
\text { Coefficient } \\
\mathrm{cm}^{2} / \mathrm{sec}\end{array}$ \\
\hline $\mathrm{NaCF}_{3} \mathrm{SO}_{3}: \mathrm{PEO}_{50}$ & $1.77 \times 10^{-4}$ & 0.5 & $2.95 \times 10^{-9}$ \\
$\mathrm{Mg}\left(\mathrm{CF}_{3} \mathrm{SO}_{3}\right)_{2}: \mathrm{PEO}_{20}$ & $1.69 \times 10^{-5}$ & 0.5 & $2.8 \times 10^{-11}$ \\
$\mathrm{Zn}\left(\mathrm{CF}_{3} \mathrm{SO}_{3}\right)_{2}: \mathrm{PEO}_{20}$ & $1.7 \times 10^{-4}$ & 0.5 & $2.83 \times 10^{-10}$ \\
$\mathrm{Cu}\left(\mathrm{CF}_{3} \mathrm{SO}_{3}\right)_{2}: \mathrm{PEO}_{\mathrm{LiCF}}$ & - & - & - \\
\hline
\end{tabular}


Table VI. Calculated Diffusion Coefficient Values for Divalent Polymer Electrolytes

\begin{tabular}{lccc}
\hline Electrolyte & $\begin{array}{c}\text { Conductivity } \\
\mathrm{S} / \mathrm{cm}\end{array}$ & $\begin{array}{c}\text { Transport } \\
\text { Number }\end{array}$ & $\begin{array}{c}\text { Diffusion } \\
\text { Coefficient } \\
\mathrm{cm}^{2} / \mathrm{sec}\end{array}$ \\
\hline $\mathrm{NaCF}_{3} \mathrm{SO}_{3}: \mathrm{PEO}_{20}$ & $3.2 \times 10^{-4}$ & 0.5 & $2.13 \times 10^{-9}$ \\
$\mathrm{Mg}_{\left(\mathrm{CF}_{3} \mathrm{SO}_{3}\right)_{2}: \mathrm{PEO}_{16}}$ & $2.5 \times 10^{-5}$ & 0.5 & $3.33 \times 10^{-11}$ \\
$\mathrm{Zn}\left(\mathrm{CF}_{3} \mathrm{SO}_{3}\right)_{2}: \mathrm{PEO}_{20}$ & $1.7 \times 10^{-4}$ & 0.5 & $2.83 \times 10^{-10}$ \\
$\mathrm{Cu}\left(\mathrm{CF}_{3} \mathrm{SO}_{3}\right) 2: \mathrm{PEO}$ & - & - & - \\
$\mathrm{LiCF}_{3} \mathrm{SO}_{3}: \mathrm{PEO}_{20}(1)$ & $1.5 \times 10^{-4}$ & 0.5 & $9.99 \times 10^{-9}$ \\
\hline
\end{tabular}

(1) M.Z.A. Munshi \& B.B. Owens, Polymer Journal, 20(7) (1988) 577.

(2) R. Huq, G. Chiodelle, P. Ferloni \& A. Magistris, J. Electrochem. Soc., 134(2) (1987) 364 .

(3) T.M.A. Abrantes, L.J. Alcanier, \& C.A.C. Sequeira, Solid State Ionics, 18 \& 19 (1986) 315.

(4) L.L. Yang, A.R. McGhie \& G.C. Farrington, J. Electrochem. Soc., 133(7) (1986) 1380.

(5) A. Patrick, M. Glasse, R. Latham \& R. Linford, Solid State Ionics, 18 \& 19 (1986) 1063.

(6) M.B. Armand, J.M. Chagabno \& M.J. Duclot, 'Fast Ion Transport in Solid', eds. Vashista, Mundy \& Shenoy, Elsevier North Holland, Inc.

(7) K. West, B. Zachau-Christiansen, and T. Jacobsen, Intl. Symp. on Polymer Electrolytes, Vol 1 (1987) 341.

(8) P.G.M. Mehroutra and W.L. Worrell, Extended Abst. \#86, Vol. 83-2 (1983), 164th Electrochemical Society Meeting. 


\section{IA. CONDUCTIVITY AND CELL STUDIES IN Na/ $\mathrm{V}_{6} \mathrm{O}_{13}$ SYSTEMS}

Over the last ten years new macromolecular materials based on polymers have been proposed as solid electrolytes suitable for applications in batteries of high specific energy $(1,2)$. However, at present there is an absence of solid electrolytes that exhibit adequately high ionic conductivities for appropriate ionic species. Since high electrical batteries have been designed for operation at these elevated temperatures. In recent years, work has been undertaken to develop an electrolyte with suitable ionic conductivity at ambient temperature, in order to cor -truct an ambient-temperature solid-state battery (3).

Although lithium anodes offer many attractive teatures such as high specific energy and high negative electrode potentials, the advantages may be overshadowed by some disadvantages such as higher cost and materials availability $(4,5)$. Therefore the use of sodium anodes may be an attractive alternative and so cells of the type $\mathrm{Na} / \mathrm{NaCF}_{3} \mathrm{SO}_{3} \cdot \mathrm{PEO}_{9} / \mathrm{V}_{6} \mathrm{O}_{13}$ have been investigated in the present research (6).

In order to achieve attractive performance levels with $\mathrm{Na} / \mathrm{V}_{6} \mathrm{O}_{13}$ polymer electrolyte systems, the electrolytes must exhibit high ionic conductivities and also chemical and electrochemical stability against practically useful electrode couples. Thus our attention has been focussed on characterizing sodium triflate polymer electrolytes by studying their conductivities, structural characteristics and celi cycling performance '7).

The conduction mechanism in polymer electrolytes is assumed to be due to $\mathrm{M}^{+}$ion transport from one lone pair site to another along the helical PEO strands. However, studies have shown that $\mathrm{Li}^{+}$transport number is less than unity. The ion transport mechanism is not well understood and remains an important research topic. It has been found (8) that the ionic conductivity of the PEO-LiX system is influenced by anion type and sait concentration. A model was proposed whereby the decrease in the ionic conductivity with increasing salt concentration was due to ion-pair formation.

Phase diagrams have been used by Gorecki (9), Minter et al. (10) and Sorenson \&

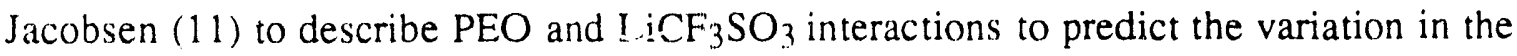


total ionic conductivity with temperature and electrolyte composition. It is now accepted that polymer electrolytes are not single-phase materials in the range of temperature and composition of interest for electrochemical batteries. A number of studies has also suggested that ion mobility is greatest in the 'amorphous' phase. This amorphous phase is more correctly term $\mathrm{d}$ the mixed phase region and is area 3 of the phase diagram (Figure 1). In this region at equilibrium, liquid (area 4) is mixed with the solid solvate $C$ of composition $\mathrm{NaCF}_{3} \mathrm{SO}_{3} \cdot \mathrm{PEO}_{4}$ (mole fraction $=0.2$ ). The electrical conductivity of the solid solvate is expected to be lower than that of the liquid, and the composite electrolyte in region 3 will have a conductivity that will depend on the relative fractions of the two phases that are present. In the single phase regions of the phase diagram, the conductivity wi'l be a function of temperature and composition. It has been shown $(12,13)$ that PEO complexes are partly crystalline at room temperature but as the temperature is increased the crystallinity of the PEO complex decreases, i.e., becomes more liquid in nature. Reasonable conductivities occur in this crystalline/liquid phase, even although the crystalline regions inhibit conductivity.

Three types of temperature dependence have been observed and discussed for electrolyte conductivity in polymer systems (14). First, for single-phase electrolytes with a high degree of crystallinity, the temperature dependence is described by an Arrhenius-type relationship:

$$
\sigma=A \exp \left(\frac{-E_{a}}{R T}\right)
$$

Even when a discontinuity is observed in the $\log \sigma$ versus $1 / \mathrm{T}$ curve, (e.g., due to a phase change), equation [1] applies to each segment. For a mixed phase electrolyte, a VogelTamman-Fulcher (VTF) equation provides a better description: 


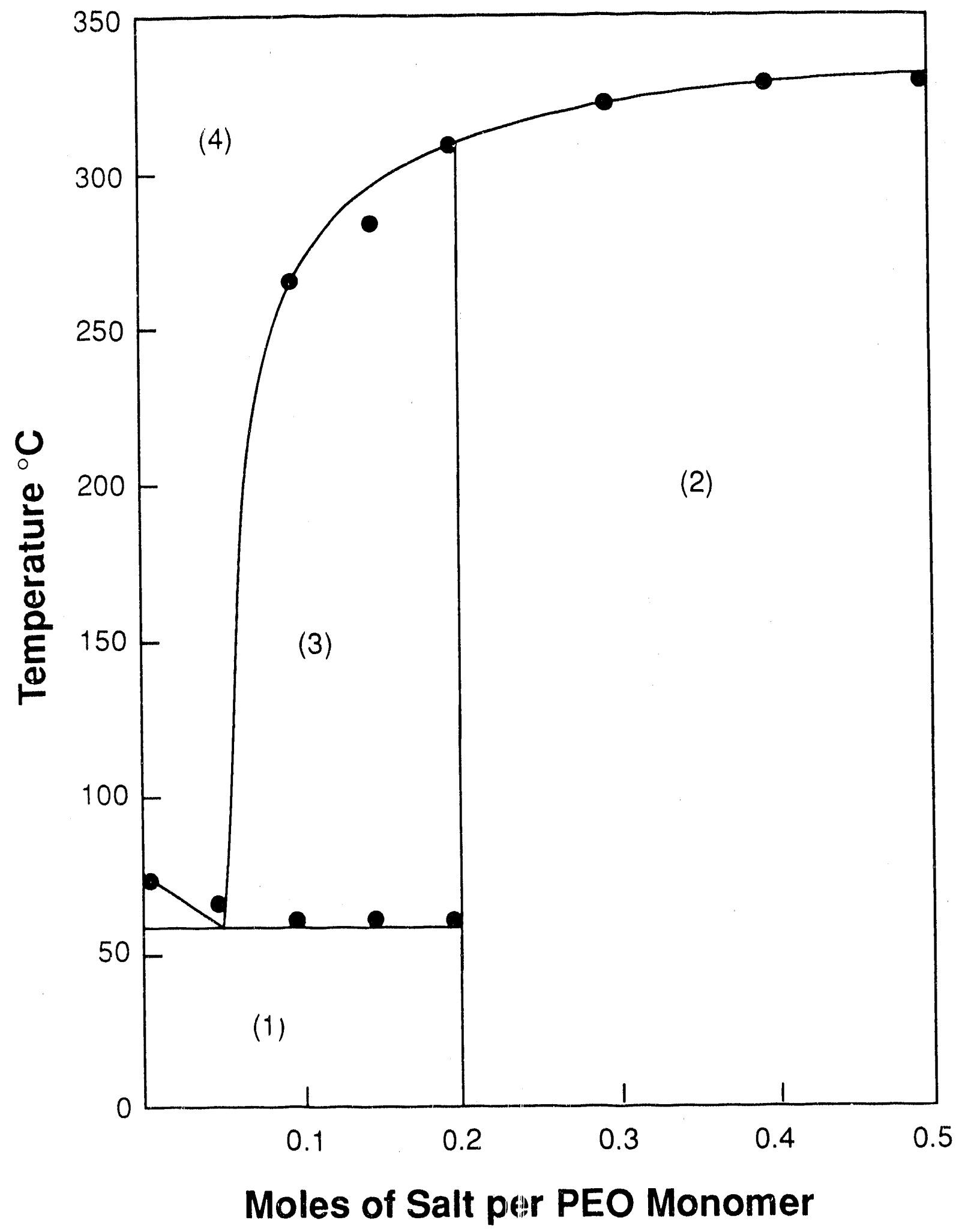

Figure 1: Phase Diagram For $\mathrm{PEO} / \mathrm{NaCF}_{3} \mathrm{SO}_{3}$ System 


$$
\sigma=A \frac{1}{\sqrt{T}} \exp \left[\frac{-E_{a}}{\kappa\left(T-T_{o}\right)}\right]
$$

where To is a temperature which can be associated with the glass transition temperature ( $\mathrm{Tg}$ ) of the electrolyte and $\mathrm{Ea}$ is a pseudo-activation energy related to the configurational entropy of the polymer chain (15). The third type of electrolyte conductivity temperature dependence is a combination of the first two.

PEO and some sodium salts have so far been characterized by James et al. (16) and Robitaile et al. (17). Robitaile et al. (17) established the phase diagram for the PEO-SCN system which then led them to establish the stoichiometry of the intermediate solvate compound to be NaSCN.PEO 3 . This was later confirmed by Hibma (18). The stoichiometry of the intermediate compound for the PEO-NaI system was found to be NaI:PEO 3 by Gorecki (9), Berthier et al. (12) and Minier et al. (13). The conductivity of these sodium salt - PEO electrolytes were also measured by other workers (Table 1). Using Table 1, it is possible to compare the conductivity of several sodium salt - PEO electrolytes with analogous lithium salt - PEO electrolytes. From this table, it is possible to conclude that in general sodium salt - PEO electrolytes have a higher conductivity than those of lithium salt - PEO electrolytes. One example is that at $80^{\circ} \mathrm{C}, \mathrm{NaCF}_{3} \mathrm{SO}_{3} \cdot \mathrm{PEO}_{4.5}$ has a conductivity of $1 \times 10^{-5} \mathrm{~s} / \mathrm{cm}$ whereas $\mathrm{LiCF}_{3} \mathrm{SO}_{3} \cdot \mathrm{PEO}_{4}$ has a conductivity of $1 \times 10^{-7}$ $\mathrm{s} / \mathrm{cm}$. It is only feasible to compare electrolytes with similar $\mathrm{M} / \mathrm{O}$ ratios $(\mathrm{M}=$ metal, $\mathrm{O}=$ oxygen) and those which appear in similar regions of the phase diagram, since electrolyte conductivity varies significantly with composition (8) and the different phase diagram regions. Also the anion type affects conductivity so only electrolytes with the same anion in the salt should be compared.

Three cells were built and cycled at different rates. In $\mathrm{Li} / \mathrm{V}_{6} \mathrm{O}_{13}$ cells, the final product of the discharge reaction is thought to be $\mathrm{Li}_{\mathrm{x}} \mathrm{V}_{6} \mathrm{O}_{13}$ where $\mathrm{x}=8$. For $\mathrm{Na}$ insertion into $\mathrm{V}_{6} \mathrm{O}_{13}, \mathrm{x}$ is unknown but is anticipated to be less than 8 because of the larger ionic radius of the $\mathrm{Na}^{+}$ion $(0.98 \AA)$ compared to the $\mathrm{Li}^{+}$ion $(0.68 \AA)$. However, for the 
purpose of comparison, the theoretical capacity of the cathode was based on $8 \mathrm{Na}$ inserting into the $\mathrm{V}_{6} \mathrm{O}_{13}$ stiucture.

$$
8 \mathrm{Na}+\mathrm{V}_{6} \mathrm{O}_{13} \rightarrow \mathrm{Na}_{8} \mathrm{~V}_{6} \mathrm{O}_{13}
$$

Based on this reaction, the cathode loadings were calculated to be $264 \mu \mathrm{Ah}$ (cell $\# 1$ ), $264 \mu \mathrm{Ah}$ (cell \#2) and $254 \mu \mathrm{Ah}$ (cell \#3) and the cells were discharged at currents of $105.6 \mu \mathrm{A}$ and $24.3 \mu \mathrm{A}$, respectively. In all cases, a constant current discharge and a constant voltage charge through a current-limiting resistor were employed except for cycle number 11, where cell \#1 was charged and discharged at constant current to obtain the coulombic efficiency.

\section{Experimental}

\section{Anode Preparation}

Sodium anodes were prepared by rolling sinall pieces of sodium between polyethylene sheets using a heavy rolling pin in a helium atmosphere glove box. In this way, smooth bright layers of sodium with thicknesses between 50 and $100 \mu \mathrm{m}$ were obtained. These thin layers of sodium were then pressed onto a stainless steel disc to give a sodium electrode.

\section{Electrolyte Preparation}

The electrolytes were prepared in $1 \%$ relative humidity dry room by the following procedure:
a) Sodium triflate $\left(\mathrm{NaCF}_{3} \mathrm{SO}_{3}\right)$ was dissolved in acetonitrile.
b) Polyethylene oxide (PEC) was dissolved in acetonitrile.
c) The above two solutions were mixed together and left until homogenized. 
d) The mixture was cast on a PTFE sheet using the doctor blade technique. Thinfilm polymer electrolytes of 15 to $35 \mu \mathrm{m}$ thick, $30 \mathrm{~cm}$ long and $20 \mathrm{~cm}$ wide were obtained.

e) Electrolytes were dried in a vacuum desiccator over $\mathrm{P}_{2} \mathrm{O}_{5}$ for at least one week. The composition of the electrolytes prepared were 1:1 PEO:salt $1.5: 1,2.33: 1,4: 1,9: 1$ and 19.1.

\section{Carhods Priparation}

The $\mathrm{V}_{6} \mathrm{O}_{13}$ cathode $u$ as prepared inside a 1 percen; relative humidity dry room by a complex mixing process involving $\mathrm{V}_{6} \mathrm{O}_{13}(74.9 \mathrm{wt} \%)$, PEO (13.5 wt\%), $\mathrm{NaCF}_{3} \mathrm{SO}_{3}$ salt $(6.6 \mathrm{wt} \%)$ and Shawinigan carbon black $(5 \mathrm{wt} \%)$ in acetonitrile. This mixture was cast directly onso aluminum foils to give a thickness of $25 \mu \mathrm{m}$ using the doctor blade technique. The cathode was dried in a vacuum desiccater over $\mathrm{P}_{2} \mathrm{O}_{5}$ for at least four days.

\section{Electrode Cell Design}

The cells were assembled using the same arrangement described elsewhere (19). Each cell was sandwiched between two stainless steel current collectors, and a clamping system was used to maintain constant pressure. The effective geometric surface area of the cathode was $1.0 \mathrm{~cm}^{2}$. Polypropylene spacers were used to separate the two electrodes. Once assembled the cells were cycled at $95^{\circ} \mathrm{C}$ and at different discharge rates. 
Conductivity Measurements

A.c. conductivity measurements from $1 \mathrm{~Hz}$ to $10 \mathrm{MHz}$ were made with a Solartron 1260 impedance/gain-phase analyzer. Sample films of known thickness were sandwiched between two stainless steel electrodes of the same diameter. These cell assemblies were mounted inside an argon-filled glove box and measurements were made in a vacuum atmosphere. Measurements were made from room temperature to $100^{\circ} \mathrm{C}$ over a period of three hours. To insure that thermal equilibrium was established, measurements at a particular temperature were made over a 15 -minute time period.

\section{Differential Scanning Calorimetry (DSC)}

The thermal analysis of the samples were studied using a Mettler DSC 30 differential scanning calorimeter. The samples were weighed in a DSC pan and hermetically sealed using the supplied crimper. The samples were first heated to $50^{\circ} \mathrm{C}$ for 450 minutes before being cooled to $25^{\circ} \mathrm{C}$. The samples were then studied over the temperature range of $25^{\circ} \mathrm{C}$ to $350^{\circ} \mathrm{C}$ at a constant heating rate of $5^{\circ} \mathrm{C}$ per minute. This heating rate has been used for similar compounds by other workers (20). The DSC traces were analyzed using a Tc10-TA processor in conjunction with a Print Swiss Matrix printer.

\section{$X$-ray Diffraction Analysis}

Small samples of electrolyte $\left(2 \mathrm{~cm}_{2}\right)$ were mounted onto an aluminum sample holder. The samples were then exposed at room temperature to $\mathrm{CuK} \alpha$ radiation with an angle of incidence varying between 5 and $100^{\circ}$. The diffraction patterns were recorded on a Seimens Logic Contro! Unit LC5(X) before being transferred to an IBM computer where the diffraction patterns were analyzed to obtain peak angle values, d-spacings, count number and relative intensity. 


\section{Besults and Discussion}

\section{Pnase Diagrams}

The phase diagram for the $\mathrm{PEO} / \mathrm{NaCF}_{3} \mathrm{SO}_{3}$ electrolyte system has been constructed from differential scanning calorimetry (DSC) data (Table 2) and is presented in Figure 1. From the phase diagram, we can see that the melting point of pure PEO is $70^{\circ} \mathrm{C}$, which is consistent with that reported in the literature (21). As $\mathrm{NaCF}_{3} \mathrm{SO}_{3}$ salt (melting point $=$ $248^{\circ} \mathrm{C}$ ) is added, the melting point of the mixture is depressed until the eutectic point at $55^{\circ} \mathrm{C}$ is reached. In area (1) crystalline $\mathrm{PEO}$ and composition $\mathrm{C}$ co-exist. Area (4) consists of a homogenized liquid phase, and area (3) con ists of liquid phase (area 4) mixed with $C$. Area 3 is often referred to as the amorphous phase. The electrolytes with the highest conductivities will be shown below to have salt mole fractions between 0.05 and 0.2 $\left(\mathrm{NaCF}_{3} \mathrm{SO}_{3}: \mathrm{PEO}_{19}\right.$ and $\left.\mathrm{NaCF}_{3} \mathrm{SO}_{3} \mathrm{PEO}_{4}\right)$, are above $60^{\circ} \mathrm{C}$, and lie in area 3 of the phase diagram.

\section{Conductivity Data}

The results of measurements taken between room temperature and $100^{\circ} \mathrm{C}$ are presented in Figure $2(\log \sigma$ versus $1(x)(0 / \mathrm{T})$. Some of the solutions (electrolytes) follow the law $\sigma=\sigma_{0} \exp (-\mathrm{Ea} / \mathrm{kT})$ either in the whole temperature range or over two linear ranges, which intersect between $55^{\circ} \mathrm{C}$ and $70{ }^{\circ} \mathrm{C}$. From Figure $2 \mathrm{a}$, it can be seen that at high salt concentrations, a single activation energy is observed because the composition is single phase, and is in region 4 of the phase diagraw. As the salt concentration in the electrolyte decreases, the conductivity changes from a single linear plot to a plot with two linear regions. Each linear region is thought to represent a phase or area in the phase diagram. That is. at temperature above $700^{\circ} \mathrm{C}$ the electrolyte is in the two-phase region (area 3). the conductivity is dominated by the liquid phase, and the activation energy reflects this dominance. The activation energy in this region is between 35 and $65 \mathrm{KJ} / \mathrm{mol}$ for all the amples in Figures 2b-2e. At lower temperature. the samples are in the aii-solid region 2 of 

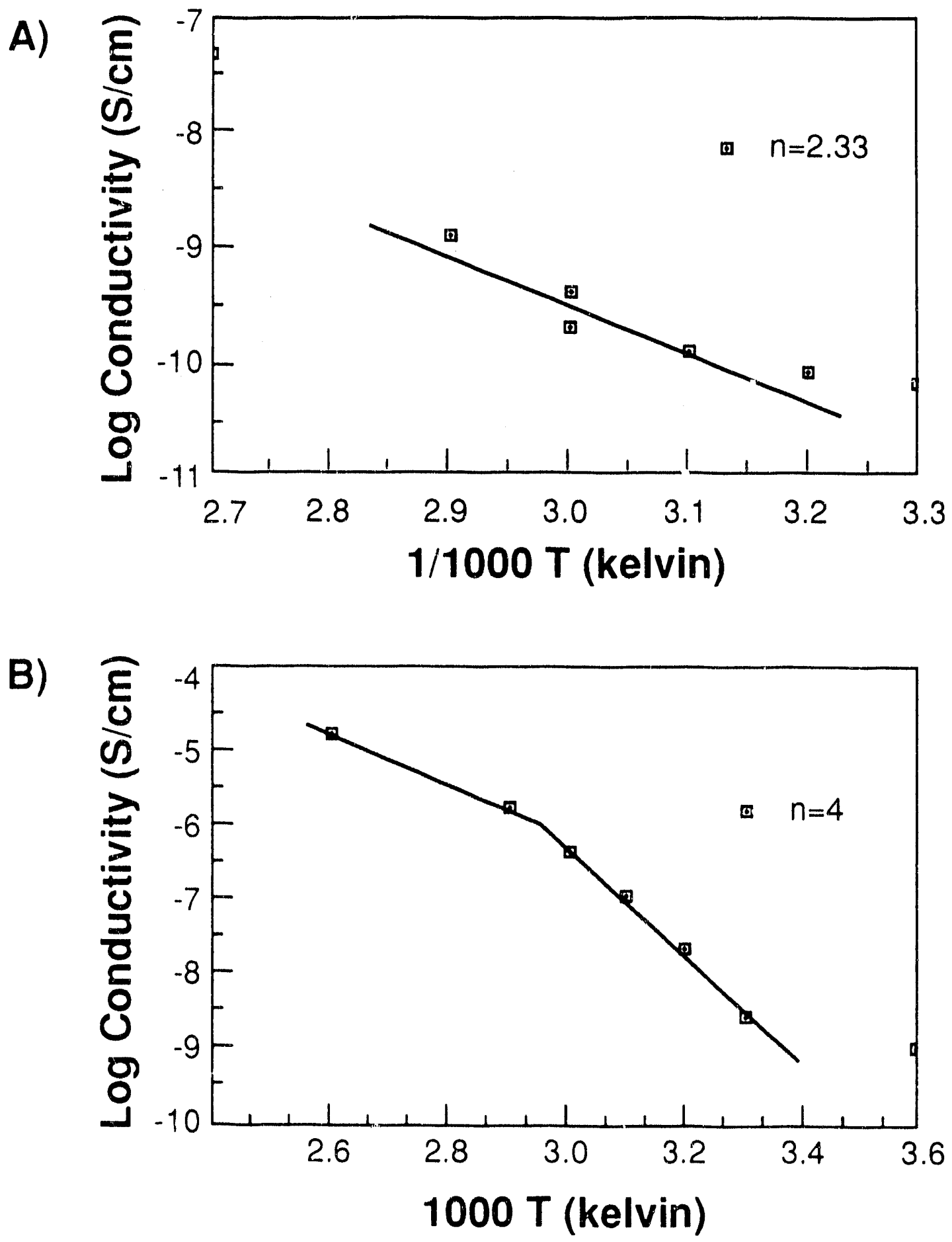

Figure 2: Arrhenius Plots for Different Salt Concentrations 

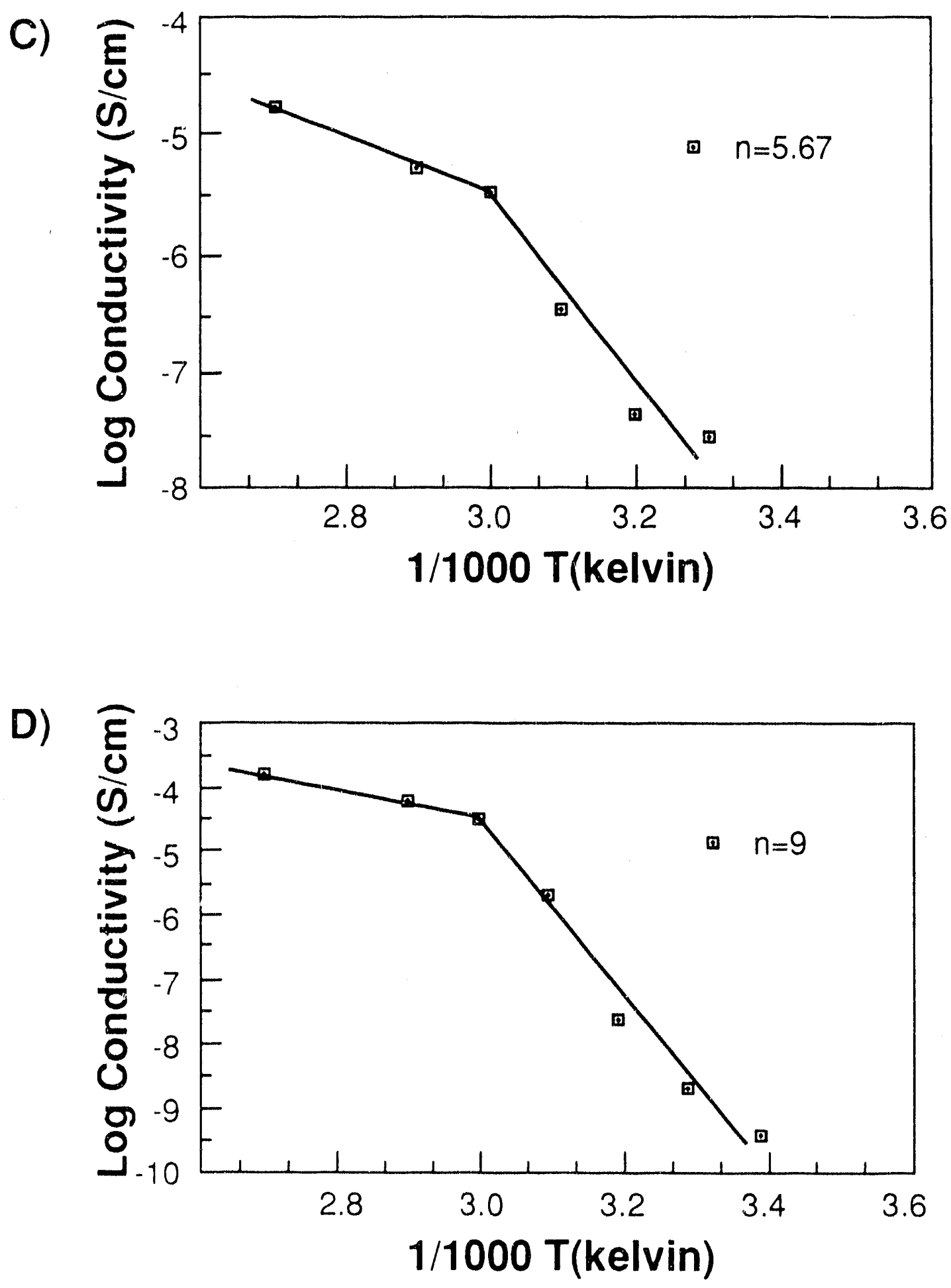

Figure 2 


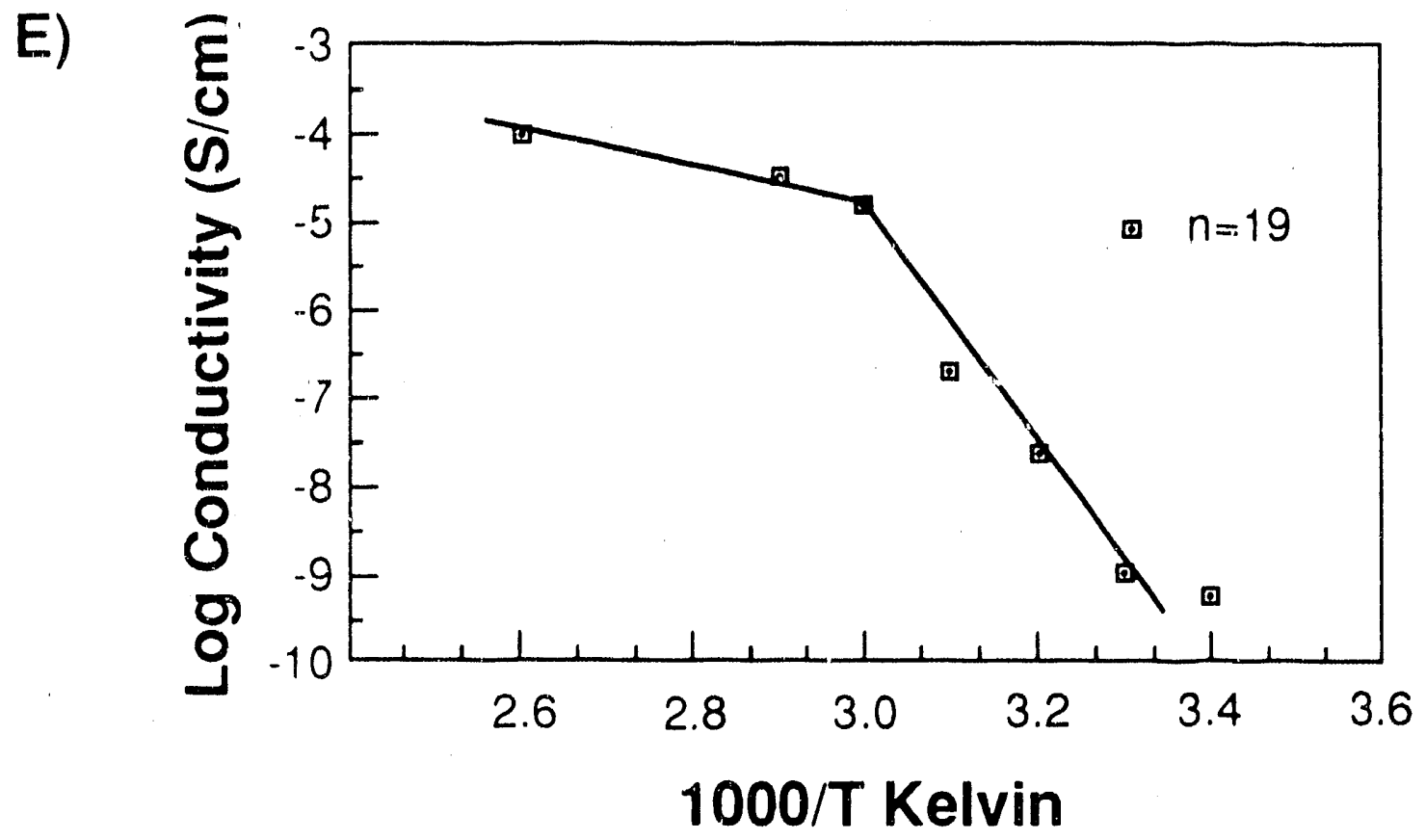

Figure 2 
the phase diagram with a mixture of crystalline PEO and the solvate $\mathrm{C}$, and the activation energies reflect the dominance of the conductivity of $\mathrm{C}$ in the sample.

The activation energies (Ea values) have been calculated for the linear regions and are presented in Table 3. In the single-phase region (area (2) there is only one linear region and hence only one activation energy Ea2. In the mixed phase regions (areas (1) and (3)), there are two linear regions and hence two activation energies have been calculated. Ea 1 corresponds to area (1) and Ea 3 corresponds to area (3) of the phase diagram. In area (1), the activation energy ( $\left.\mathrm{Ea}_{1}\right)$ decreas s with increase in mole fraction of salt. (This is due to the inter section of the linear regions becoming less pronounced with increase in the mole fraction of salt.) Also the activation energies corresponding to area (3) are much lower than those corresponding to area (1) and area (2), with that of area (2) being lower than those from area (1). The conductivity was alway's found to be highest in area (3) and the lowest in area (2).

From Figure 3 , it can be seen that at $100^{\circ} \mathrm{C}$, the conductivity of the electrolyte is at a maximum at a mole fraction of salt of 0.1 , with a decrease at lower and higher mole fractions. A similar pattern was also observed by Ferloni et al. (22) for the $\mathrm{LiClO}_{4}$ :PEO system.

\section{X-ray diffraction data}

An $x$-ray diffraction pattern was obtained for each of the compositions studied as well as for pure PEO and pure $\mathrm{NaCF}_{3} \mathrm{SO}_{3}$ salt, from which Bragg angle values, d-spacing and the relative intensity of the diffraction lines were obtained. A summary of the data is given in Table 4. Some of the peak angle values obtained from the solutions (electrolytes) are due to the solutions themselves, and some are due to pure PEO or pure salt. However, some pure salt and pure PEO peak angle values are very close together, so that when a peak angle value close to this is obtained from the solution, it is impossible to determine $w$, tether it is from pure PEO or pure salt. Therefore these peaks will be ignored in this discussion. 


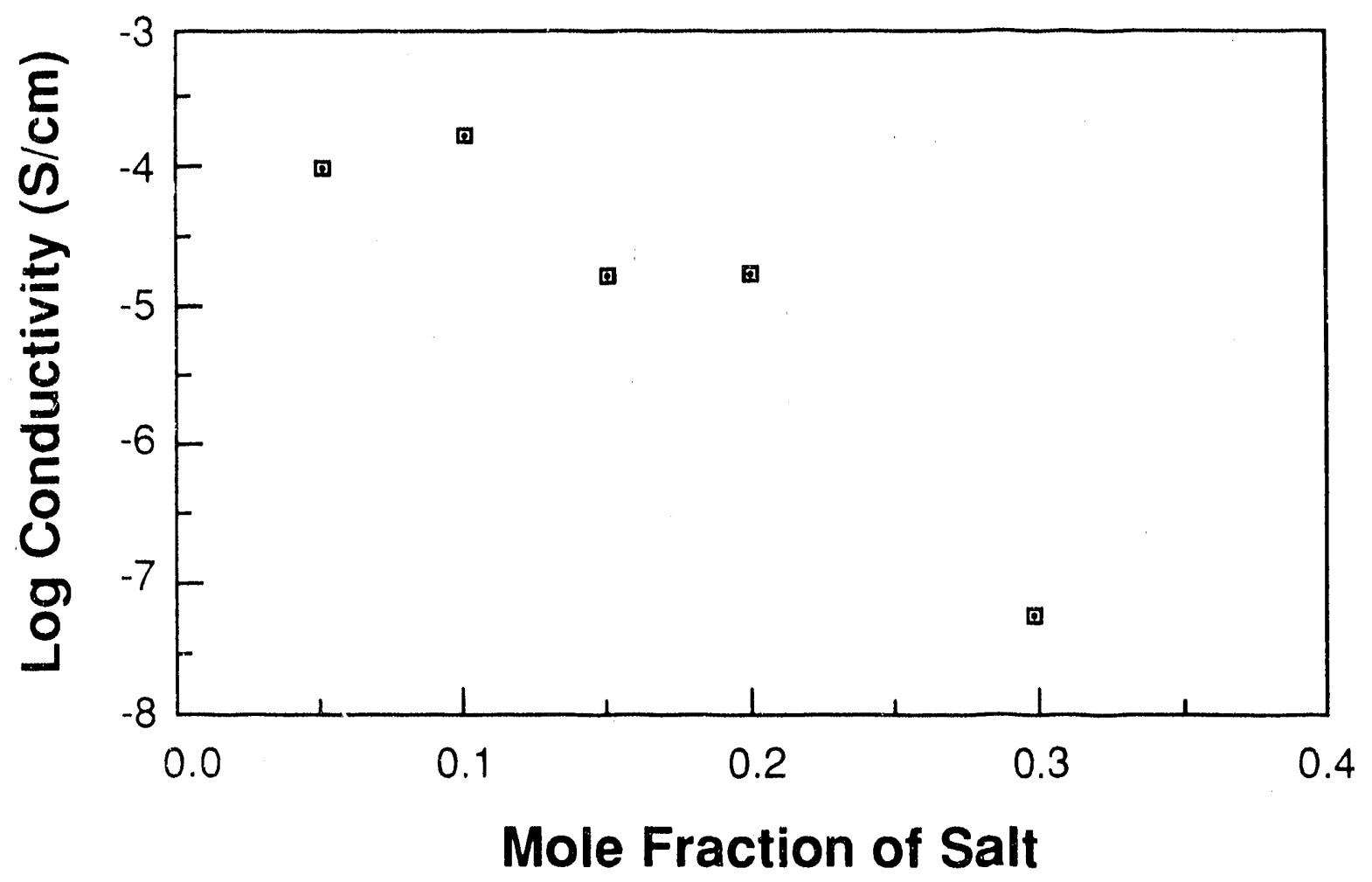

Figure 3: Log Conductivity versus Mole Fraction of $\mathrm{NaCF}_{3} \mathrm{SO}_{3}$ Salt at $100^{\circ} \mathrm{C}$. 
If we look at the peaks observed in the single phase region of the phase diagram $(n=1.5$, 2.33) i.e., area 2 , it can be seen that there are no pure PEO peaks and also at a salt mole frac ion of 0.4 , there are no peaks due to pure salt, which suggests that all the PEO and salt present has been used to form composition $\mathrm{C}$ of the phase diagram. The number of sample peaks observed are fairly constant throughout the whole composition range and also the peaks themselves are fairly consistent suggesting that only one $\mathrm{PEO} / \mathrm{NaCF}_{3} \mathrm{SO}_{3}$ complex is formed of composition $C$. In the mixed phase region $(n=5.67-19)$, there are peaks present which are due to pure PEO and pure salt, therefore not all the PEO and salt has formed composition $C$.

From the above electrolyte characterization, it is possible to predict that an electrolyte of composition of $\mathrm{NaCF}_{3} \mathrm{SO}_{3} \cdot \mathrm{PEO}_{9}$ should be used in solid-state sodium batteries at temperatures above $70^{\circ} \mathrm{C}$, since it is at this composition and temperatures that the highest conductivities are observed.

\section{Cell Cycling Studies}

The initial open circuit voltage (OCV) of the three cells studied was between 2.9 and $3.0 \mathrm{~V}$, at $100^{\circ} \mathrm{C}$. Other cells of th. 'type gave OCV's as high as $3.2 \mathrm{~V}$, which could be due to better contacts between the anode, electrolyte and cathode.

A plot of voltage versus number of sodium ions inserted into the cathode, (per $\mathrm{V}_{6} \mathrm{O}_{13}$ molecule), for the three discharge rates, is reported in Figure 4. The cut-off voltage was $1.25 \mathrm{~V}$. It is seen that for cell \#3, operating at the lower current density, up to $3.25 \mathrm{Na}$ can be incorporated into the $\mathrm{V}_{6} \mathrm{O}_{13}$ structure. The specific energy calculated for this cell from the first discharge is $260 \mathrm{Wh} / \mathrm{kg}$ of the cathode material, as compared to the theoretical value of $640 \mathrm{Wh} / \mathrm{kg}$ for $8 \mathrm{Na}$ and an average cell voltage of $1.5 \mathrm{~V}$. At low rates of discharge, the initial capacity is considerably larger than at high rates. Also from Figure 4 we can see that for each discharge rate, levelling of the discharge curve occurs when 0.4 sodiums have been inserted into the cathode lattice. If the first part of Figure 4 is magnified 


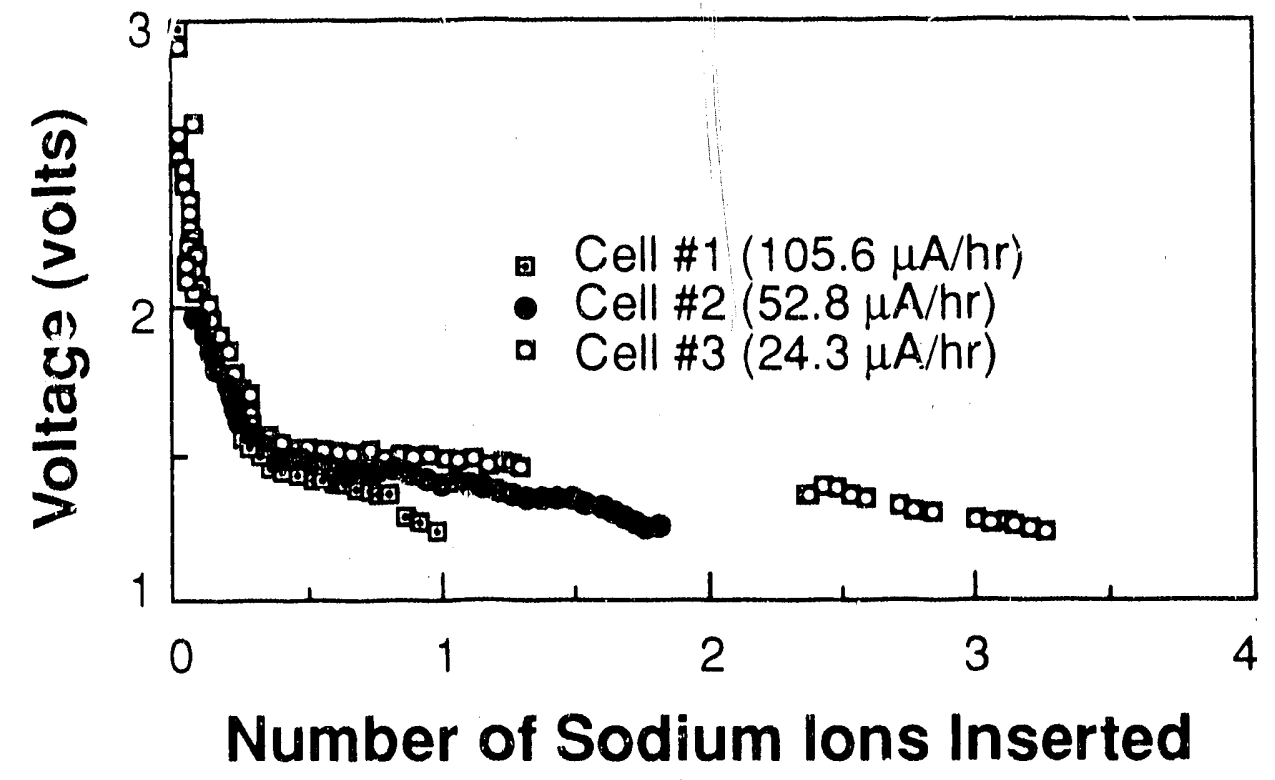

Figure 4: Emf vs Composition for Three Discharge Rates. 
(Figure 5), two other regions of inflection can be observed between $1.85-2.20 \mathrm{~V}$ and 1.62 $-1.78 \mathrm{~V}$. Since the inflections occur at roughly the same point for each discharge rate it is suggested that the plateau and two regions of inflection are due to a change in the uxidation state of the $\mathrm{V}_{6} \mathrm{O}_{13}$ cathode (23). Another factor that may give rise to these plateaus is the apparent continuous increase in the IR drop of the cell during discharge as seen in lithium cells (24), and this may apply to sodium cells as well. It is believed that the increase may be the result of a change in the electrolyte resistivity due to transport of the counter ion towards the anocie, as well as changes taking place at the cathode.

Figure 6 shows a plot of a number of sodium ions inserted versus number of cycles, for cells \#1 and \#2. For both discharge rates, the number of sodium ions being inserted stabilizes after the first few cycles. For cell (\#2 (52.8 $\mu \mathrm{A}$ rate), this stabilization occurs after 3 cycles and one $\mathrm{Na}$ is inserted into the cathode per $\mathrm{V}_{6} \mathrm{O}_{13}$ molecule. For cell $\# 1$ (105.6 $\mu \mathrm{A}$ rate), $0.25 \mathrm{Na}$ are inserted per $\mathrm{V}_{6} \mathrm{O}_{13}$ molecule after the first four cycles. The sharp decrease in the number of sodium ions inserted into the cathode during the first few cycles is consistent with the work of West, et al. on alternative cathode materials (2529). This may be due to sodium ions entering some region in the cathode from which it is difficult for them to be removed; i.e., these sodium ions become irreversible. Once the irreversible positions in the cathode become occupied, the coulombic efficiency of the insertion/deinsertion process is around $100 \%$ as measured at cycle number 11 for cell \#1 and shown by the plateau in Figure 6.

The above work suggests high stability and good reversibility for the sodium polymer electrolyte system. Although only a limited number of cycles have been made so far, initial results indicate cell feasibility and go sd cycling efficiency.

\section{Conclusions}

DSC, conductivity data and $x$-ray diffraction data show that below $\mathrm{X}_{\mathrm{NaCF}_{3} \mathrm{SO}_{3}}=$ 0.2, two phases exist at room temperature, a crystalline PEO phase and a crystalline 


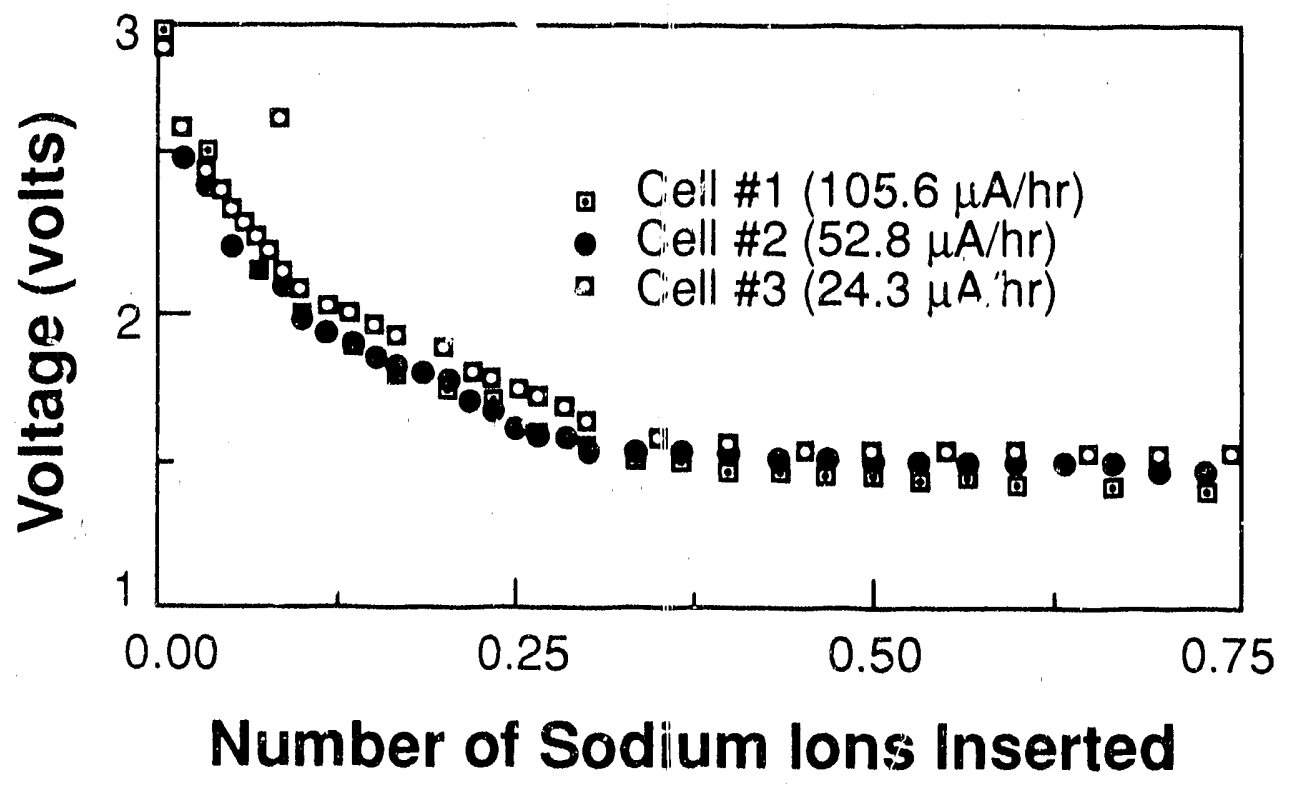

Figure 5: Emf vs Composition for Three Discharge Rates. 


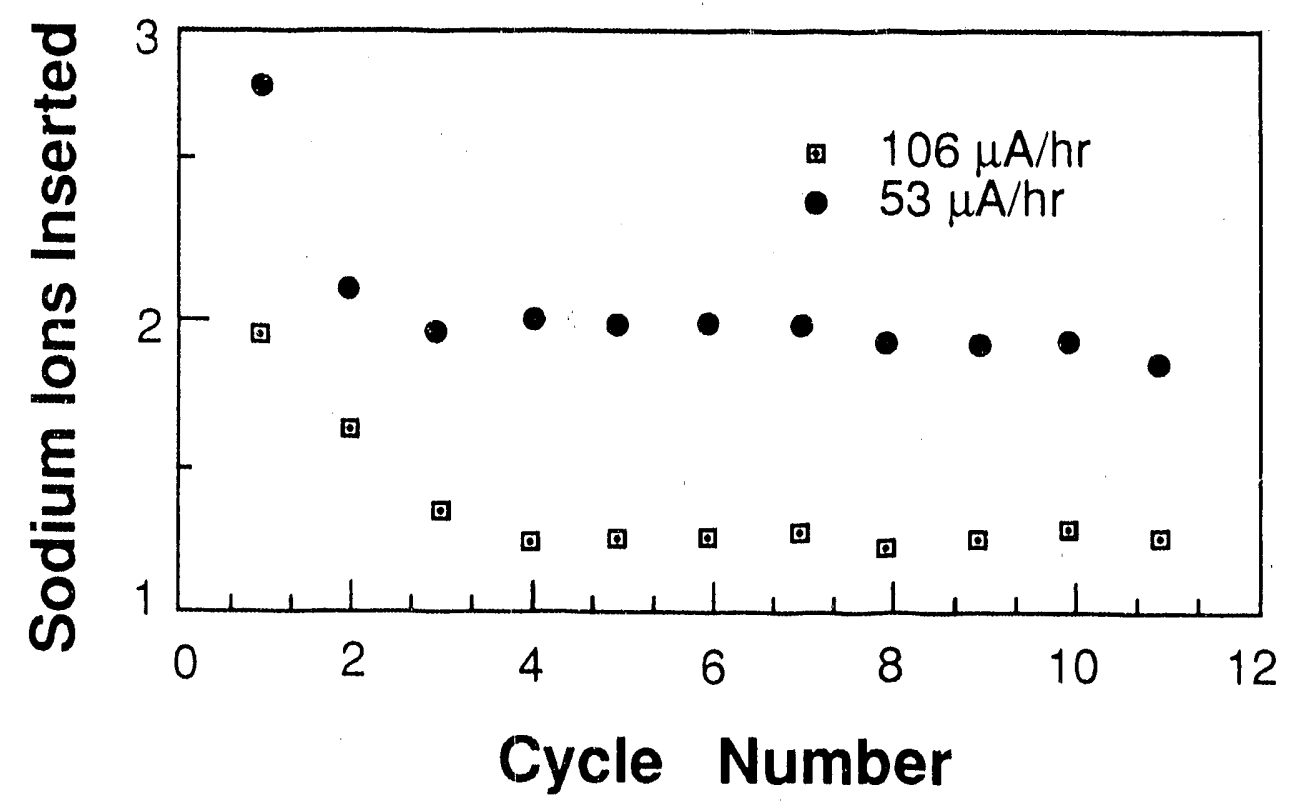

Figure 6: Number of Sodium lons Inserted vs Cycle Number. 
intermediate compound. Above $\mathrm{X}_{\mathrm{NaCF}_{3} \mathrm{SO}_{3}}=0.2$, only the crystalline intermediate compound is observed.

Both the DSC and conductivity data show that above $60^{\circ} \mathrm{C}$ (when $\mathrm{X}_{\mathrm{NaCF}_{3} \mathrm{SO}_{3}}<$ 0.2) a mixed phase is present which has a higher conductivity than the crystalline phase

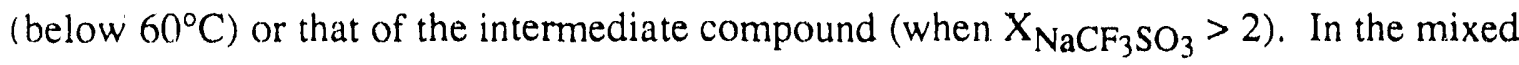
phase region (area (3), the high conductivity is probably due to the presence of liquid and the transport of sodium ions will take place predominantly through the liquid material. In general, liquids are more conducting than the equivalent solid material. From the results, we propose that an electrolyte of composition $\mathrm{NaCF}_{3} \mathrm{SO}_{3} \cdot \mathrm{PEO}_{9}$ should be used in solidstate sodium batteries at temperatures above $70^{\circ} \mathrm{C}$. Even if concentration gradients are setup within the electrolyte (i.e., if the transport number of the sodium ion is less than 1) the above composition will still be the best, and the behavior of the battery will reflect the change of composition as current is passed.

In the present study, the phase diagram and conductivity data have been used to describe $\mathrm{PEO}$ and $\mathrm{NaCF}_{3} \mathrm{SO}_{3}$ interactions in order to predict the variation in ionic conductivity with temperature and electrolyte composition. It has been shown that in the ranges of temperature and composition of interest for electrochemical batteries that the polymer electrolytes do not have a single phase but consist of a mixed phase. It is in this mixed phase (area 3 ) above $60^{\circ} \mathrm{C}$ that the highest conductivities are observed. The conductivities depend on the relative fractions of the liquid phase from area 4 and composition $\mathrm{C}$ from are 2 that are present. In the single-phase regions of the phase diagram, the conductivity is also a function of temperature and composition.

The conductivity values shown here seem to be comparable to the equivalent lithium system and thus would be expected to give high specific energy in an electrochemical cell. So far for the $\mathrm{Na} / \mathrm{V}_{6} \mathrm{O}_{13}$ cell system a specific energy of $260 \mathrm{Wh} / \mathrm{Kg}$ have been demonstrated (6) which is comparable to the $\mathrm{Li} / \mathrm{V}_{6} \mathrm{O}_{13}$ system. Also this work suggests high stability and good reversibility for the sodium-polymer electrolyte system. Although 
on!y a limited number of cycles have been made so far, initial results indicate cell feasibility and good cycling efficiency.

\section{References}

1) M.B. Armand. J.M. Chabagno, M.J. Duclot, Polyethers as Solid Electrolytes, in Fast Ion Transport in Solids, ed. P. Vashista (North Holland, Amsterdam, 1979) 131.

2) M.B. Anmand, Solid Stitie Ioniics, 9/10 (1983) 745.

3) M.Z.A. Munshi \& B.B. Owens. Proceedings of the 169th Meeting of the Electrochemical Society, Boston, MA, May 1986.

4) M.Z.A. Munshi, A. Gilmour, B.B. Owens \& W.H. Smyrl, Proceedings of the 174th Meeting of the Electrochemical Society, Chicago, IL Oct. 1988.

5) K. West, B. Zachau-Christiansen and T. Jacobsen, Intl. Symp. on Polymer Electrolytes, 1, (1987) 1847.

6) M.Z.A. Munshi, A. Gilmour, B.B. Owens \& W.H. Smyrl, J. Electrochem. Soc., $136(6)(1989) 1847$.

7) A. Gilmour, W.H. Smyrl, \& B.B. Owens, In preparation.

8) M.Z.A. Munshi \& B.B. Owens, Polymer J., 20 (1988) 577.

9) W. Gorecki, PhD the sis, Grenoble University, France (1984).

10) M. Minier. C. Berthier and W. Gorecki, J. Phys., 45 (1984) 739.

11) P.R. Sorensen and T. Jacobsen, Polymer Bulı, 9, (1983) 47.

12) C. Berthier, W. Gorecki, M. Minier, M.B. Armand, J.M. Chabagno \& R. Rigand, Solid Sitate Ionics, 11, (1983) 91.

13) M. Minier. C. Berthier and W. Gorecki, Solid State Ionics, 9/10(1983) 1125.

14) S. Feldberg, J. Am. Chem. Soc.. 106 (1984) 4671.

15 B.L. Papke, M.A. Ratner and D.F. Shriver. J. Electrochem. Soc., 24 (1982) 1694.

16) D. B. James, R.S. Stein. W.J. Macknight. Bull. Am. Phys. Soc. 24 (1979) 479.

(7) C. Robitaille \& J. Prudd'Homme, 65th Canadian Chemical Congress, Toronot, May 1982. Abst \#.MA-10.

13) T. Hibma. Solid State Ionics, 9/10(1983)1101.

19) F.M. Gray. I.R. MacCallum \& C.A. Vincent. Solid State Ionics, 18/19 (1986) 282. 
20) M.Z.A. Munshi \& B.B. Owens, Solid State lonics, 26 (1988) 41.

21) M.Z.A. Munshi \& B.B. Owens, Applied Physics Communications, 6(4) (1986-87) 279.

22) P. Ferloni, G. Chiodelli, A. Magistris \& M. Sanesi, Solid State Ionics, 18/19 (1986) 265.

23) M.Z.A. Munshi \& B.B. Owens, Solid State Ionics, 27 (1988) 251.

24) M.Z.A. Munshi \& B.B. Owens, Solid State Ionics, 27 (1988) 46.

25) K. West, B. Zachau-Christiansen \& T. Jacobsen, Intl. Symp. on Polymer Electrolytes, 1 (1987) 341.

26) K. West. B. Zachau-Christiansen, T. Jacobsen, \& S. Atlung, J. Electrochem. Soc., 132 (1985) 3061.

27) K. West. B. Zachau-Chustiansen, T. Jacobsen \& S. Atlung, Ext. Abs. 6th Int. Conf. Solid State Ionics, 1987.

28) B. Zachau-Christiansen, K. West \& T. Jacobsen, Solid State Ionics, 1987.

29) S. Skaarup, K. West, B. Zachau-Christiansen \& T. Jacobsen, Proc. Int. Seminar on Solid State Ionics Devices, Eds., B. V.R. Chowdari \& S. Radhakrishna, (World Sci. Pub. Co. Pte, Lid) (1988). 


\section{Table_1}

\section{Endothermic Peak Positions for the}

Electrolytes Obtained from DSC

$\begin{array}{ccc}\begin{array}{c}\text { Electrolyte } \\ \mathrm{NaCF}_{3} \mathrm{SO}_{3}: \text { PEO }\end{array} & \begin{array}{c}\text { Salt Mole } \\ \text { Fraction }\end{array} & \text { Peak Position(s) } \\ \left({ }^{\circ} \mathrm{C}\right)\end{array}$

\section{Table 2}

Activation Energy (Ea) Values for the Lineir Regions in the Arrhenius Plots

$\begin{array}{cccc}\begin{array}{c}\text { Salt Mole } \\ \text { Fraction }\end{array} & \begin{array}{c}\mathbf{E a}(\mathbf{1}) \\ \mathbf{k J} \mathbf{~ m o l}^{-1}\end{array} & \begin{array}{c}\mathbf{E a}(\mathbf{2}) \\ \mathbf{k J} \mathbf{~ m o l}^{-1}\end{array} & \begin{array}{c}\mathbf{E a}(\mathbf{3}) \\ \mathbf{k J ~ m o l} \mathbf{l}^{-1}\end{array} \\ 0.05 & 252.7 & - & 36.4 \\ 0.1 & 258.5 & - & 45.96 \\ 0.15 & 136.7 & - & 46.3 \\ 0.2 & 127.2 & - & 63.2 \\ 0.3 & - & 114.9 & -\end{array}$




\section{IB. EXPLORATORY STUDIES WITH Na/PPY RECHARGEABLE CELLS}

The oxidation and reduction of poly(pyrrole) have often been studied with $\mathrm{Li}^{+}$salts, but seldom with other cations. The anion of the electrolyte is inserted upon oxidation of the polymer, and removed upon reduction back to the neutral state. In the present study, $\mathrm{NaCF}_{3} \mathrm{SO}_{3}$ in $\mathrm{PEO}$ was used as the electrolyte in a thin-film cell with $\mathrm{Na}$ as the anode and PPY as the cathode. Upon cycling such cells, the electrolyte is partially depleted in the charge part of the cycle and replenished during discharge. The conductivity of the electrolyte may change significantly during cell cycling unless an excess of electrolyte is utilized.

The advantages of a conducting, electroactive polymer cathode are that thin films of the maitrial may be deposited (by electropolymerization) on substrate current collectors. The films conform to the shape of the substrate surface, the thickness of the films may be controlled by controlling the total charge during electropolymerization, the micromorphology of the films may be controlled by the conditions of deposition, diffusion in the films is often more rapid than in oxide insertion electrodes, and the films are less susceptible to mechanical damage that may arise during cell cycling. PPY has been found to be stable in aqueous and oxygen environments and has excellent behavior in many electrolytes. The disadvantages that partially offset the positive characteristics are a limit to the reversible cycling of the films, and large changes of conductivity of the films between the reduced (low conductivity) state and the oxidized (high conductivity) state. We observed good reversibility of the PPY films in the cells studied here, and no stability for the limited number of cycles used here.

The $\mathrm{Na} / \mathrm{NaCF}_{3} \mathrm{SO}_{3}$-PEO/PPY cei! was fabricated and studied in a thin film configuration. The electrode reactions were

$$
\begin{aligned}
& \mathrm{Na}=\mathrm{Na}^{+}+\mathrm{e}^{-} \\
& {\left[\left(\mathrm{PPY}^{\mathrm{x}}\right)\left(\mathrm{CF}_{3} \mathrm{SO}_{3}^{-}\right)_{\mathrm{x}}\right]+\mathrm{xe}^{-}=\mathrm{PPY}+\mathrm{xCF}_{3} \mathrm{SO}_{3} .}
\end{aligned}
$$


Sodium triflate was used as the electrolyte in PEO. The assembly of the cell was carricd out as outlined below. Electrodeposition of PPY on the Pi substrate was carried out from a solution composed of $0.2 \mathrm{M} \mathrm{NaCF}_{3} \mathrm{SO}_{3}$, and $0.2 \mathrm{M}$ pyrrole (monomer) in acetonitrile. Electropolymerization was done at a constant voltage of $800 \mathrm{mV}$ vs SCE. 0.38 coulombs of charge was passed, part of which was used for polymerization and part of which was used to oxidize the growing film. The electrode diameter was $2 \mathrm{~cm}$ (total area $=0.785$ $\mathrm{cm}^{2}$ ). The thickness of the PPY film was $3 \mu \mathrm{m}$, and the total amount of PPY was $3.49 \mathrm{X}$ $10^{-4} \mathrm{gm}\left(2.36 \times 10^{-4} \mathrm{~cm}^{3}\right)$. The theoretical capacity of PPY is $65 \mathrm{Ah} / \mathrm{kg}$ for films prepared in $\mathrm{LiClO}_{4}$, but the analogous capacity is not known for the films prepared in sodium triflate. Na was pressed onto a quartz substrate and was present in excess. The electro!yite in the assembled cell was $\mathrm{PEO} \cdot \mathrm{NaCF}_{3} \mathrm{SO}_{3}$ mixture (8:1), 30- $\mu$ m thickness.

The assembled cells had an open circuit voltage of $2.45 \mathrm{~V}$ at $100^{\circ} \mathrm{C}$, and a theoretical capacity of $22.7 \mu \mathrm{A}$-hrs. The initial cell resistance was $5800 \Omega$. Cell discharge was carried out at a constant current of $7.6 \mu \mathrm{A}$, which corresponds to a $\mathrm{C} / 3$ rate. Discharge was continued to a cell voltage of $1.5 \mathrm{~V}$. Recharge was carried out at the same constant current of $7.6 \mu \mathrm{A}$ to $3.1 \mathrm{~V}$. The results of several cycles are shown in Figures 1 and 2 . The observed capacity was 45 percent of theoretical and the coulombic efficiency of the first cycle was 70 percent. Subsequent cycles approached a steady behavior so that the discharge curves could be nearly superimposed on one another. 


\section{Figure 1. DISCHARGE CURVES \\ FOR CYCLES 1 AND 5.}

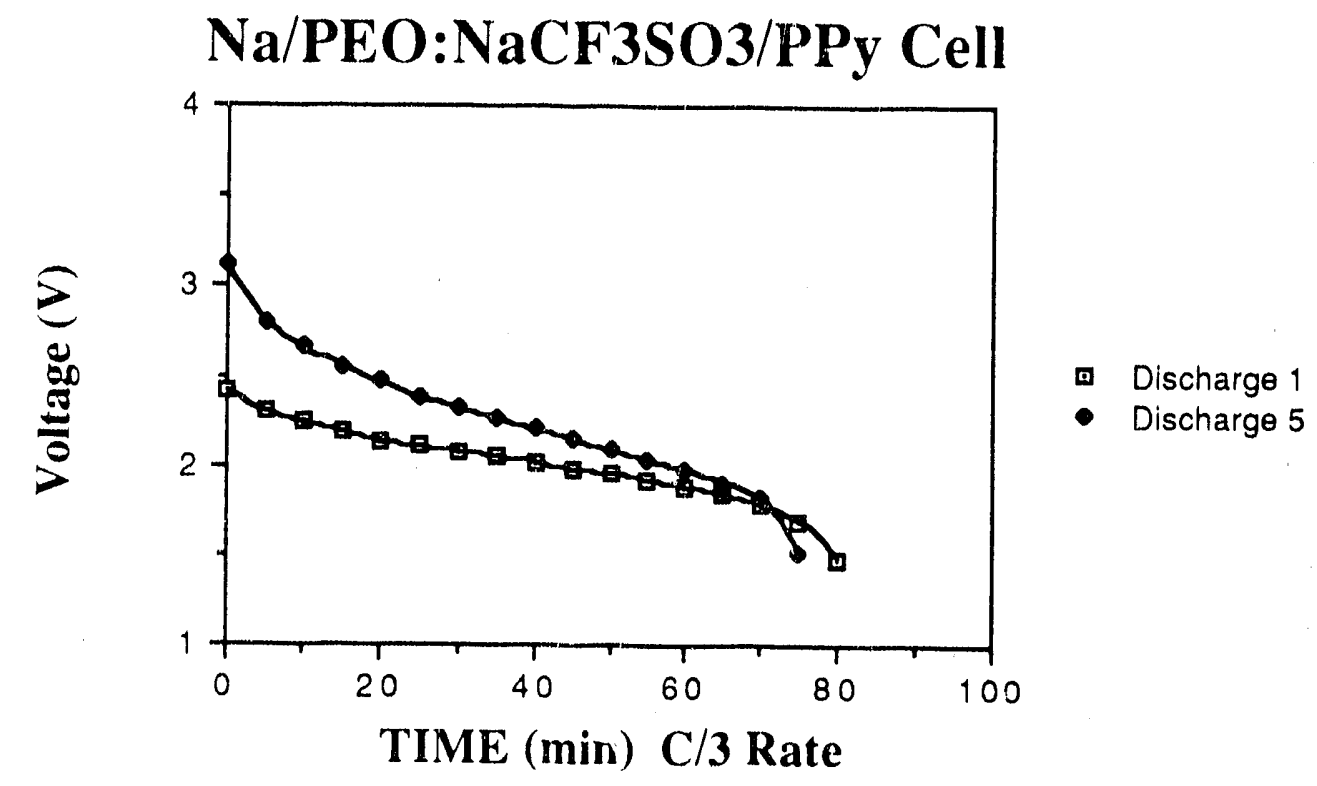

$\mathrm{Na} / \mathrm{PEO}: \mathrm{NaCF}_{3} \mathrm{SO}_{3} / \mathrm{PPy}_{\mathrm{Pell}}$

Theoretical Capacity $=22.7 \mu \mathrm{A} \cdot \mathrm{hrs}$

Coulombic efficiency $=70 \%$

Observed Capacity $=40.45 \%$ theoretical 


\section{Figure 2. DISCHARGE CURVES FOR CYCLES 2 TO 5.}

Na/PEO:NaCF3SO3/PPy Cell

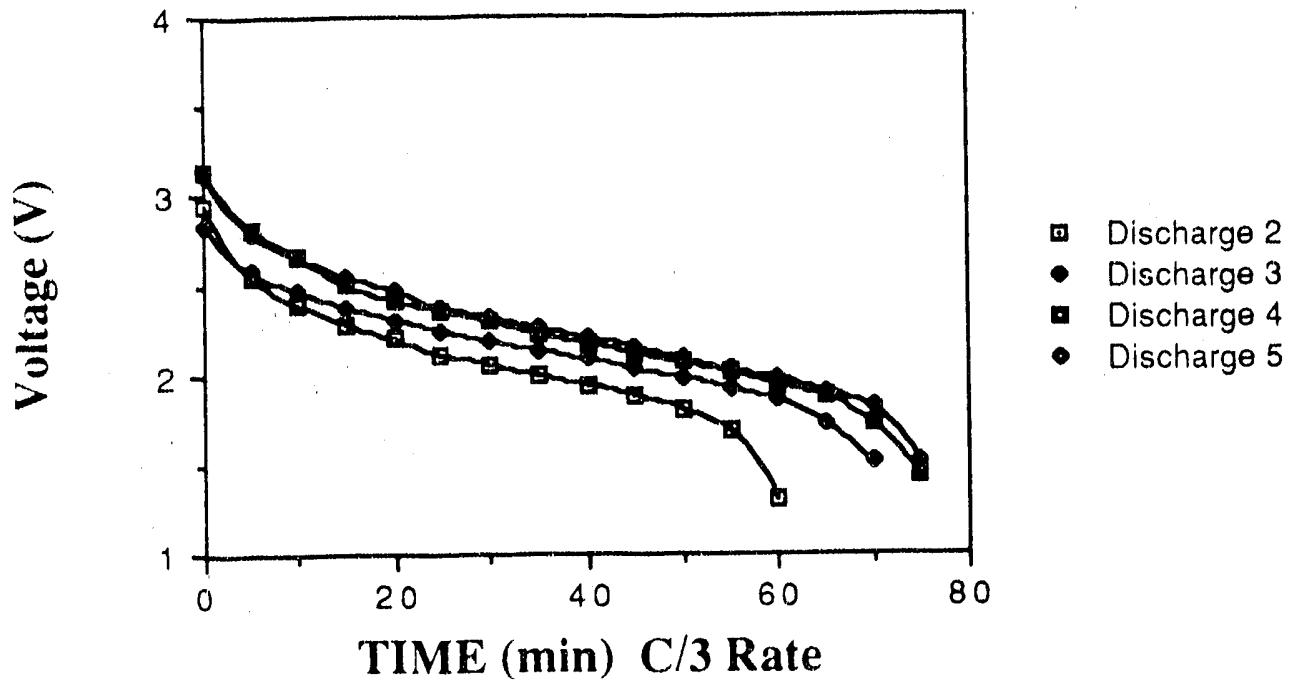

$\mathrm{Na} / \mathrm{PEO}: \mathrm{NaCF}_{3} \mathrm{SO}_{3} / \mathrm{PPy}$ Cell:

Theoretical Capacity $=22.7 \mu \mathrm{A}-\mathrm{hrs}$

Coulombic efficiency $=70 \%$ Observed Capacity $=\mathbf{4 0 . 4 5} \%$ theoretical 


\section{IMPEDANCE AND CAPACITANCE OF ELECTROACTIVE THIN FILM MATERIALS}

Assembly of thin-film structures requires the preparation of films that are very thin, very flat (exhibiting a low degree of surface roughness), and uniform in thickness. Locally smooth films aid in achieving a uniform current distribution along the film as well. A nonuniform current distribution that persists during cycling of electroactive materials (e.g., oxidation followed by reduction of the entire film) can produce increasingly rough surfaces. On a larger scale, uniformity is necessary to obtain good contact between adjacent film layers.

Application of electroactive thin-film materials include energy storage with either high energy or high power, electrochromic switching, and stabilization of oxide covered metals and semiconductor surfaces. Electronically conducting polymers such as poly(acetylene), poly(thiophene) (PT), and poly(pyrrole) (PPY) have been widely investigated because of their interesting electrochemical, electronic, and optical properties. Oxidation and reduction processes that transform the polymers from the insulating to the conducting state are reversible, if the charge injected is less than about 0.3 equivalent electronic charge per monomer unit. Reversible oxidation/reduction may be carried out chemically, but precise control by electrochemical techniques has been widely used. For polymers like PT or poly(3-methylthiphene) (P3MT), cycle voltammetry from the (insulating) neutral state to the (conductive) oxidized state may be carried out repeatedly for many cycles with little or no degradation. Both polymer films show a linear dependence of anodic peak current on sweep rate. This is the classic relationship for film-constrained reversible oxidation/reduction processes. Redox polymer films such as poly(vinylferrocene) (PVF) have similar behavior, but may be doped 100 percent by oxidation of the pendant ferrocene centers along the vinyl backbone. Inorganic materials that show similar properties have also be intensively studied. That is, insertion materials such as $\mathrm{TiS}_{2}, \mathrm{WO}_{3}, \mathrm{~V}_{6} \mathrm{O}_{13}$, and graphite may be reversibly oxidized and reduced with high 
Blue) have many similar properties as well. Cations such as $\mathrm{Li}^{+}$are typically injected in the redox process at insertion oxides and sulfides instead of anions as is the case for many electroactive polymers. In Table I are listed the electrochemical properties of several polymers studied in the present program. The redox capacity of Prussian Blue films (determined in our laboratory) has been found to be as large as $3000 \mathrm{~F} / \mathrm{cm}^{3}$, and about $55,\left(000 \mathrm{~F} / \mathrm{cm}^{3}\right.$ for $\mathrm{V}_{6} \mathrm{O}_{13}$.

Table I. Electrochemical Properties of Polymer Film Electrodes

\begin{tabular}{lcccc}
\hline & PVF & PPY & P3MT & PT \\
\hline $\mathrm{i}_{\mathrm{O}}\left(\mathrm{MA} / \mathrm{cm}^{2}\right)$ & $1-10$ & $1-5$ & 63 & 0.4 \\
$\mathrm{C}_{\mathrm{dl}}\left(\mu \mathrm{F} / \mathrm{cm}^{2}\right)$ & $2-9$ & $1-10$ & 0.3 & 4 \\
$\mathrm{D}_{\mathrm{CT}}\left(\mathrm{cm}^{2} / \mathrm{sec}\right)$ & $10^{-7-10^{-8}}$ & & $10^{-7}-10^{-8}$ & $10^{-9}$ \\
$\mathrm{C}_{\mathrm{V}}\left(\mathrm{F} / \mathrm{cm}^{3}\right)$ & $100-10_{-5}$ & $(100-1000)$ & $100-1000$ & $100-500$ \\
\hline
\end{tabular}

Charge injection rates were determined from impedance measurements at high frequency. The high frequency behavior enables the rate of charge injection/removal to be studied. At intermediate frequencies, the impedance behavior is dominated by diffusion in the polymer film and the diffusion coefficient may be measured in this region. At the lowest frequencies, the entire film is oxidized or reduced as a unit, and the impedance of the film is completely capacitive (hence the term redox capacitance). Our laboratory was the first to describe the three regions of behavior for PVF films, but have since found the behavior to be characteristic of PT, P3MT, PPY polymer films and inorganic films such as prussian blue. The earlier work of Ho, Raistrick, and Huggins on $\mathrm{WO}_{3}$ suggests that the same pattern will also be seen for inorganic insertion oxides and sulfides. 
prussian blue. The earlier work of Ho, Raistrick, and Huggins on $\mathrm{WO}_{3}$ suggests that the same pattern will also be seen for inorganic insertion oxides and sulfides.

The low-frequency redox capacity may be quite high as indicated above for the polymer films and insertion films. For high power applications, the thin films are electrochemical capacitors. It is of interest to determine the highest frequency at which the films are dominated by the redox capacity behavior. It is known that the thickness of the film and the diffusion coefficient together determine the limiting frequency response in this region. Thinner films and higher diffusion coefficients extend the capacitive response to higher frequencies. Figure 1 shows the impedance behavior of a PVF films as an example. The low-frequency capacitive behavior is observed up to frequencies of $300 \mathrm{~Hz}$. It is more difficult to form very thin films of the insertion oxides and sulfides, and diffusion coefficients are typically lower than in electroactive polymer films, so it will be more

\section{Figure 1. REDOX CAPACITY OF PVF FROM IMPEDANCE MEASUREMENTS}

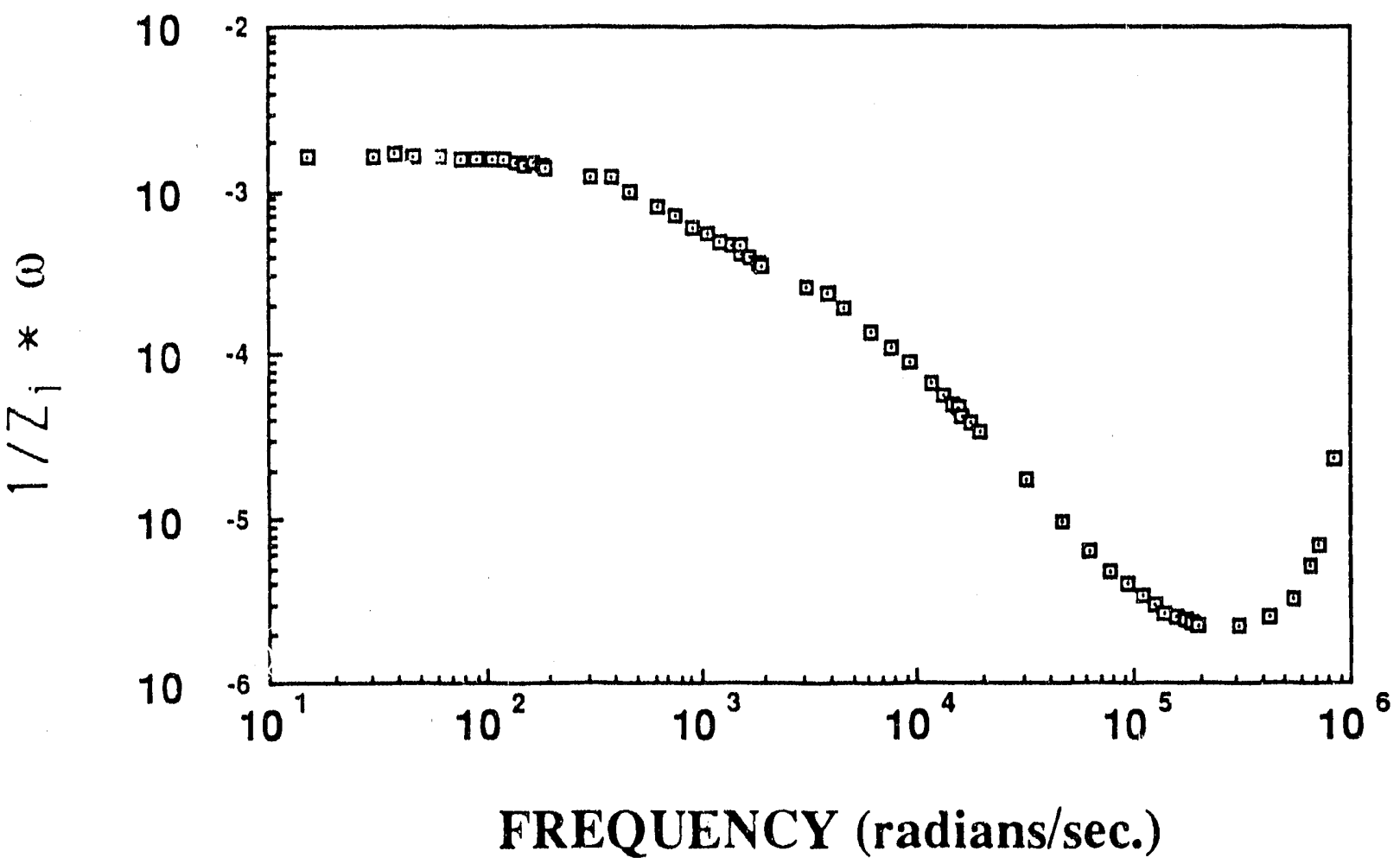


The redox capacity of electroactive films may be calculated for several ideal cases. For a thin redox film that obeys ideal Nernstian thermodynamics, the redox capacity is

$$
\frac{C_{L}}{V_{f}}=\frac{Q_{0}}{V_{M}}\left(\frac{z F}{R T}\right) \times(1-x)
$$

where $\mathrm{C}_{\mathrm{L}} / \mathrm{V}_{\mathrm{f}}$ is the redox capacity $\left(\mathrm{F} / \mathrm{cm}^{3}\right), \mathrm{Q}_{\mathrm{o}}$ is the total charge associated with redox sites in the film, $V_{M}$ is the molar volume, $(\mathrm{zF} / \mathrm{RT})$ has the usual meaning, and $\mathrm{x}$ is the fraction of the sites that are oxidized. From impedance data, one may calculate the redox capacity from

$$
\frac{C_{L}}{V_{f}}=\frac{i}{\left(\omega Z_{i m a g}\right) V_{f}}
$$

where $V_{f}$ is the volume of the film. An ideal lattice gas has been used to model insertion films from which the redox capacity may be calculated

$$
\frac{C_{L}}{V_{f}}=\left(\frac{1}{V_{M}}\right) z F\left(\frac{d x}{d E}\right)
$$

which may be shown to be identical with Equation 1 if the film obeys Nernstian thermodynamics. These relationships are quite useful in calculating the redox characteristics of new materials, and from published data in the literature. We are preparing a review of published data for electroactive thin-film materials. 
APPENDIX A. Papers published in 1989 from work supported in this program.

1. "Impedance Analysis of Poly(vinylferrocene) Films Spin-Coated on Metal Substrates", M. Lien and W.H. Smyrl, Proceedings of the Symposium on Transient Techniques on Corrosion Science and Engineering, Eds. W.H. Smyrl, et al. The Electrochemical Society (Pennington, NJ) 1989, p. 286.

2. "Impedance Characterization of Electrochemistry of Conducting Polymers," W.H. Smyrl and Chi-Hum Paik, Ibid., 1989, p. 270.

3. "Sodium $/ \mathrm{V}_{6} \mathrm{O}_{13}$ Polymer Electrolyte Cells," M.Z.A. Munshi, A. Gilmour, W.H. Smyrl, and B.B. Owens, Electrochem. Soc. 136, 1847 (1989).

4. "Intercalation Reactions of Monovalent and Divalent Cations in $\mathrm{V}_{6} \mathrm{O}_{13}$ Single Crystals," M.Z.A. Munshi, A. Gilmour, B.B. Owens, and W.H. Smyrl, in Proceedings of the Symposium on Materials and Processes for Li Batteries, edited by K.M. Abraham and B.B. Owens, The Electrochemical Society (Pennington, NJ) 1989, p. 145.

5. "A Comparison of Lithium and Divalent Cationic Polymer Electrolytes in Secondary Solid State Batteries," A. Gilmour, M.A.Z. Munshi, B.B. Owens, Ibid, 1989, p. 190. 

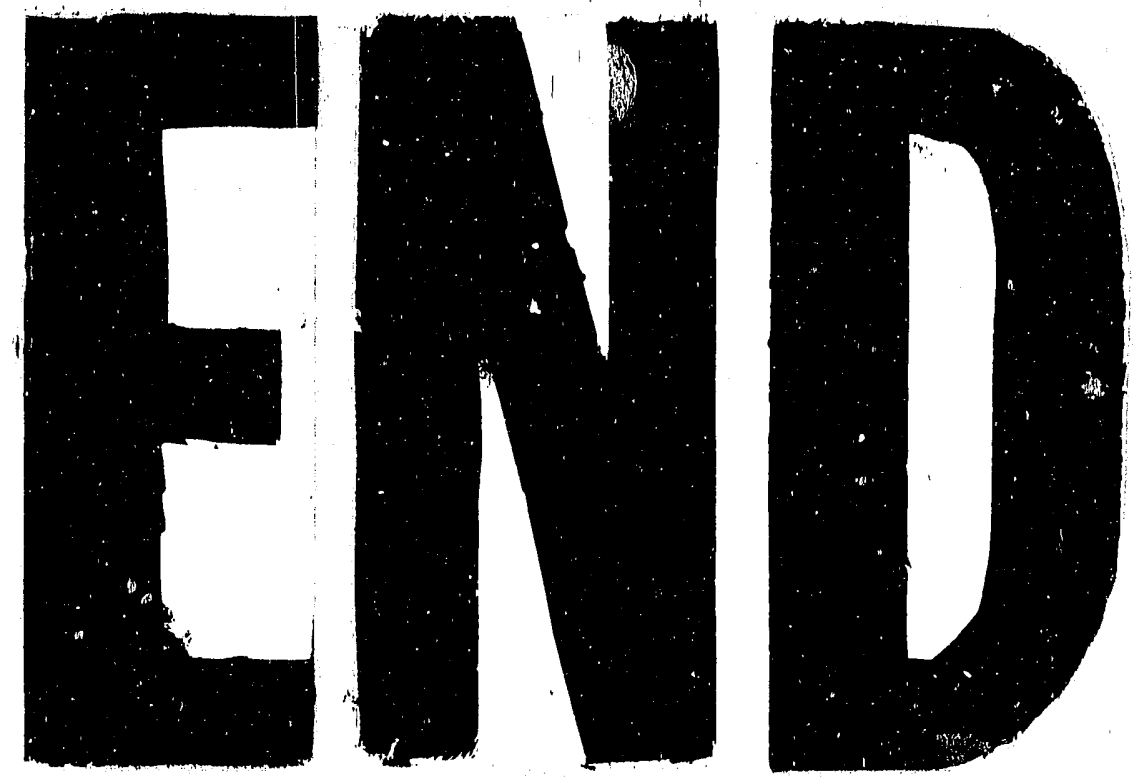

4
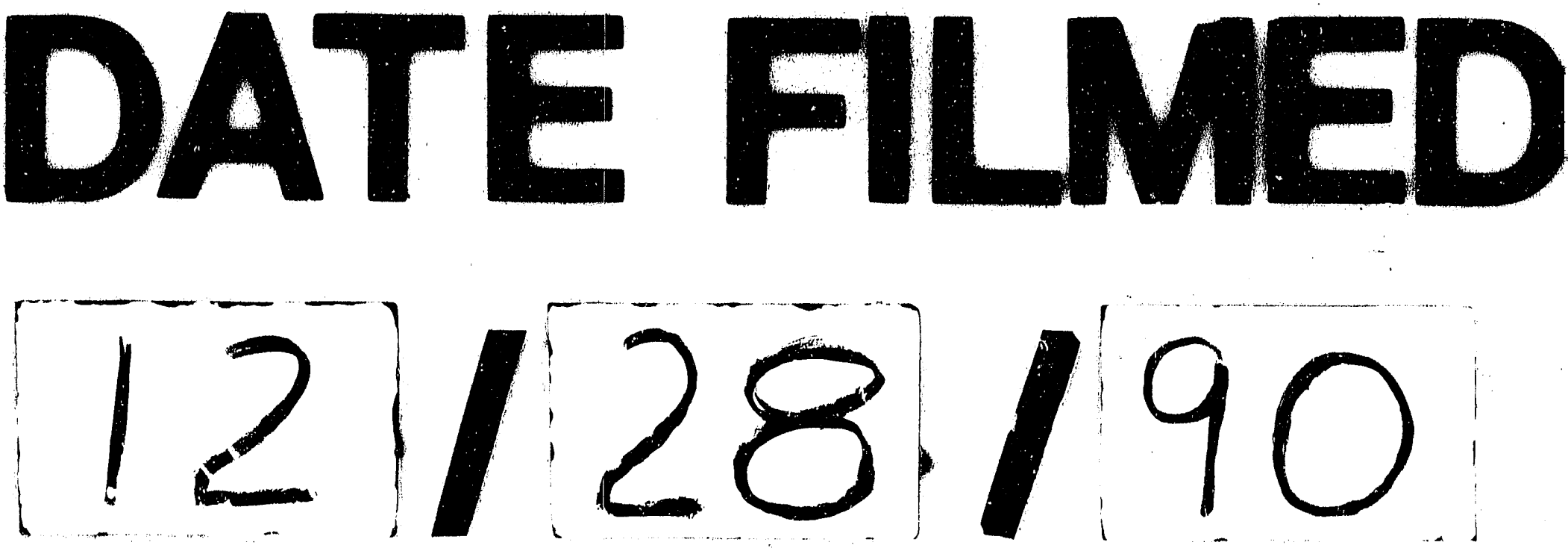
$\ddots$ 